OPEN ACCESS

Edited by:

Vera Bin San Chan,

Clemson University, United States

Reviewed by:

Vengatesen Thiyagarajan, The University of Hong Kong,

Hong Kong

Gary H. Dickinson,

The College of New Jersey,

United States

*Correspondence:

Linsheng Song

Ishsong@dlou.edu.cn

Specialty section:

This article was submitted to

Marine Molecular Biology

and Ecology,

a section of the journal

Frontiers in Marine Science

Received: 16 February 2018

Accepted: 28 January 2019

Published: 19 February 2019

Citation:

Song $X$, Liu Z, Wang $L$ and Song L (2019) Recent Advances of Shell Matrix Proteins and Cellular Orchestration in Marine Molluscan

Shell Biomineralization.

Front. Mar. Sci. 6:41.

doi: 10.3389/fmars.2019.00041

\section{Recent Advances of Shell Matrix Proteins and Cellular Orchestration in Marine Molluscan Shell Biomineralization}

\author{
Xiaorui Song' ${ }^{1}$ Zhaoqun Liu' ${ }^{1}$, Lingling Wang ${ }^{1}$ and Linsheng Song ${ }^{1,2,3 *}$ \\ ${ }^{1}$ Liaoning Key Laboratory of Marine Animal Immunology, Dalian Ocean University, Dalian, China, ${ }^{2}$ Laboratory for Marine \\ Fisheries Science and Food Production Processes, Qingdao National Laboratory for Marine Science and Technology, \\ Qingdao, China, ${ }^{3}$ Liaoning Key Laboratory of Marine Animal Immunology and Disease Control, Dalian Ocean University, \\ Dalian, China
}

Biomineralization refers to the dynamic physiological processes whereby living organisms elaborate mineralized tissues. The existence of extremely abundant molluscan species shows the diversity of mineralized tissues, since the majority of them (Conchifera) produce shells that vary in size and shape. Over the past decades, great progress has been made on the study of the cellular biology of shell biomineralization. The construction of the molluscan shell is the archetype of biologically controlled mineralization which requires specialized cellular machinery. It has been so far demonstrated that the cells involved in shell formation come from two different sources: outer mantle epithelial cells (OME) and circulating hemocytes. OMEs secrete the organic matrix, among which shell matrix proteins (SMPs) determine mineralogical and crystallographic properties of shell. Circulating hemocytes take part in the deposition of intracellular biominerals and deliver them to the mineralization sites. Many novel SMPs have been identified by using molecular biology techniques (i.e., gene cloning, in situ hybridization, immunohistochemistry) coupled with high-throughput sequencing data (genome, proteome, secretome and transcriptome), and their corresponding functions during the shell formation have also been confirmed. The cellular activity of OME and hemocytes during shell formation are significantly increased during shell regeneration process. A potential cellular basis model for molluscan shell formation is proposed. The shell matrix proteins, mostly secreted from OME, and a few secreted from hemocytes or other organs, are either directly delivered to the mineralization site via exosome or classical secretory pathway, or first transported to the hemolymph, and then engulfed by hemocytes (mainly granulocytes), which will disintegrate and release shell proteins and $\mathrm{CaCO}_{3}$ crystals at the mineralization front. OME and hemocytes may also be involved in the nucleation and remodeling process of $\mathrm{CaCO}_{3}$ mineral. These cells and cell products work co-operatively to produce an organo-mineral shell, which is composed of various biomineral ultra-structures and macromolecular organic components.

Keywords: biomineralization, outer mantle epithelial cells, shell matrix proteins, hemocytes, marine molluscs 


\section{INTRODUCTION}

Biomineralization refers to an extraordinary dynamic biological process whereby a living organism produces biomineral structures (a rigid skeleton or a non-skeletal mineral) at ambient temperature in environments ranging from polar to tropical (Simkiss and Wilbur, 1989; Cusack and Freer, 2008; Shi et al., 2013; Tang et al., 2018). Biomineral structures are of wide existence in nature with polymorphism and multiple functions. So far, at least 60 different biominerals have been identified to play versatile functions, including tissues support, embryonic and UV protection, shelter against predation, nutrition, reproduction, gravity, light or magnetic field perceptions, storage of mineral ions (Cusack and Freer, 2008; Marin et al., 2008; Islam and Peng, 2018). In the metazoan world, $\mathrm{CaCO}_{3}$ skeletons are the most abundant and most commonly encountered biominerals (Lowenstam and Weiner, 1989; Simkiss and Wilbur, 1989; Marin et al., 2007; Cusack and Freer, 2008; Marin et al., 2008). The phylum Mollusca is the second largest invertebrate phylum, which benefits from the protection from their external biomineralized structure, the shell, a kind of the mastery of cellular-engineered microstructures (Kocot et al., 2016).

Molluscan separate the biomineral formation from the ambient environment (Rahman and Shinjo, 2012) and exhibit a huge diversity of biomineral morphologies, such as shells from most molluscs, epithelial spicules of the basal mollusk Wirenia argentea (Solenogastres) (Todt and Wanninger, 2010), scales and plates in bivalves, operculum in gastropod Rapana venosa (Hashimoto et al., 2012), intracellular detoxifying granules in the common garden snail Helix aspersa (Howard et al., 1981), egg capsules of the Patagonian neogastropod Odontocymbiola magellanica (Bigatti et al., 2010), love dart of land snails (Lodi and Koene, 2016), pearls from pearl oyster, statoconia in Aplysia californica (Kondrachuk and Wiederhold, 2004), and statoliths in Nassarius reticulatus (Caenogastropoda) (GalanteOliveira et al., 2014). The shell is the most well-known $\mathrm{CaCO}_{3}$ biominerals in molluscan animals, which contributes to support and protect them from predators, pathogens and to some extent from other environmental conditions, such as desiccation, wave action and iceberg damage (Kouchinsky, 2000; Cusack and Freer, 2008). Molluscs utilize a highly crosslinked protein layer (periostracum) and the outer mantle epithelial cells (OME), between where they elaborate a matrix comprising various macromolecules serving as the framework (Wilbur and Saleuddin, 1983; Lowenstam and Weiner, 1989; Addadi et al., 2006). Generally, the molluscan shell is made of approximately $95 \% \mathrm{CaCO}_{3}$ and $1-5 \%$ organic matrix. $\mathrm{CaCO}_{3}$ exists as different crystal polymorphs (i.e., calcite, aragonite, vaterite) under natural conditions, and is arranged in layers with a distinctive pattern to form complex biomineral microstructures in molluscan shells. So far, more than 30 different biomineral microstructures of mollusc $\mathrm{CaCO}_{3}$, such as nacre, foliate, prismatic, cross lamellar, and homogeneous microstructure, have been documented based on the scanning electron microscopy (SEM) observations (Chateigner et al., 2000; Kouchinsky, 2000; Furuhashi et al., 2009).
A typical molluscan shell (i.e., the shells of the mussel, the oyster, the abalone and the nautilus) exhibits a trilayered structure: the outermost layer periostracum (a thin organic leathery layer), and two calcified layers (the outer prismatic layer and the inner nacreous layer) (Saruwatari et al., 2009). The prismatic layer is composed of elongated calcitic crystals in the form of prisms perpendicular to the periostracum. The nacreous layer, namely the inner lustrous shell layer, is composed of laminar structure made up of aragonite crystals, organized in a brick wall-like structure (Marie et al., 2012). Because of its extremely high fracture-resistance properties, nacre is considered as the most fascinating mollusk shell microstructures (Marin et al., 2012). As mentioned above, molluscan shell is a composite of inorganic mineral (mainly $\mathrm{CaCO}_{3}$ ) and organic matrix, which is secreted from the mantle epithelium, and comprised of proteins, peptides, lipids, and carbohydrates (Lowenstam and Weiner, 1989; Addadi et al., 2006). The cooperation mechanism of these disparate components in producing a highly structured biomineralized shell has not been fully understood despite decades of investigations. Scientists have traditionally recognized the matrix-mediated hypothesis, which states that the organic matrix exclusively control the molluscan shell formation by providing the framework, inducing crystal nucleation, and regulating crystal growth extracellularly, thereby forming the crystal morphologies that are unique to the various layers of molluscan shell (Addadi et al., 1987, 2006; Lowenstam and Weiner, 1989). However, these results were mostly revealed from in vitro experiments through mimicking internal microenvironment, thus the effect of matrix proteins on shell mineralization is questionable (Sikes et al., 2000; Mount et al., 2004). One alternative to the matrix-mediated hypothesis is the cell-mediated hypothesis, which proposes that crystal nucleation occurs in hemocytes or OME, and that crystal-bearing cells transport nascent crystals intracellularly to the mineralization front (Mount et al., 2004; Gong et al., 2008a; Xiang et al., 2014). Although the cellular basis has been reported in many other biomineralization, such as osteoclasts and primary mesenchyme cells involved in bone and spicule formation in vertebrates and echinoderms, respectively (Wilt, 2002; Kylmaoja et al., 2016), this hypothesis still largely scraps the dominant paradigm in molluscan biomineralization, and has been supported by increasing evidence, which will be introduced in the following text (Mount et al., 2004; Fleury et al., 2008; Johnstone et al., 2008, 2015; Cho and Jeong, 2011; Kong et al., 2015; Li et al., 2016). To date, cells coming from two different sources have been observed involved in shell formation: (1) OMEs mediate shell formation by either directly involving in the nucleation and remodeling process of $\mathrm{CaCO}_{3}$ mineral (Kong et al., 2015) or secreting the organic matrix, among which shell matrix proteins (SMPs) regulate the diversity of shell shapes by orchestrating the $\mathrm{CaCO}_{3}$ crystals in a specific manner (Lowenstam and Weiner, 1989; Zhang and Zhang, 2006; Marin et al., 2008; Ivanina et al., 2017); and (2) hemocytes participate in the deposition of intracellular $\mathrm{CaCO}_{3}$ crystals and deliver them to the mineralization site (Mount et al., 2004; Fleury et al., 2008; Kádár, 2008; Mount and Pickering, 2009; Cho and Jeong, 2011; Johnstone et al., 2015; Li et al., 2016; Ivanina et al., 2017). In this 
review, we give a brief description of the OME- and hemocytemediated cellular biomineralization of marine molluscs.

\section{OME-MEDIATED SHELL MINERALIZATION IN MOLLUSCS}

The mantle tissue can be divided into several specialized regions (inner epithelium, internal tissues, and outer epithelium) from inside to outside (Figure 1). The outer epithelium is known to be related to the shell formation process, owing to its proximity to the mineralization front (Nudelman et al., 2006). The OMEs on the surface of outer epithelium further comprise a subtle cell zonation (mantle edge and mantle pallial), and appears to be strictly associated with the different microstructures of shell formation (Marin et al., 2008). Generally, SMPs secreted from the mantle edge cells are involved in the prismatic layer formation, while SMPs produced from mantle pallial cells participate in nacreous layer formation (Miyamoto et al., 1996). This zonation has been evidenced in molluscs by in situ hybridization or immunohistology techniques. For example, the localization of Pif 80 was checked by means of immunohistochemical SEM image analysis, and positive immunosignals could be observed throughout the nacreous layer after incubation with the antibody to Pif 80 (Suzuki et al., 2009). Shell organic constitutes synthesized by OME can be generally classified into two categories: insoluble (mostly chitin and silk) and soluble proteins. The insoluble proteins often act as a framework for shell formation and involves in the strengthening of shell mechanical properties, while the soluble ones are essential factors determining mineralogical and crystallographic properties (Addadi et al., 2006; Morse et al., 2007; Cusack and Freer, 2008; Marin et al., 2008; Marie et al., 2012). For example, some molecules function as $\mathrm{Ca}^{2+}$ chelators, mineral nucleators or inhibitors (Nudelman et al., 2006; Yan et al., 2007), some regulate crystal shape (Albeck et al., 1993), and some determine which $\mathrm{CaCO}_{3}$ polymorph will form (Falini et al., 1996; Fu et al., 2005; Marie et al., 2012). This section summarizes the SMPs identified so far from the shells of molluscs, and emphasizes the physiological function of several critical SMPs through biochemical and micromorphological studies during shell biosynthesis.

\section{The Molecular Characteristic of SMPs}

Shell matrix proteins are crucial factors for biomineralization processes, and the evolution of SMPs can reflect the diversification characters of molluscan shell (Marin et al, 2008; Marie et al., 2012). Traditionally, SMPs were retrieved from the soluble or insoluble organic fractions after dissolving the shell powder into calcium-chelating agents (i.e., EDTA or weak acid) (Marin et al., 2008). The soluble organic fractions were usually enriched in acidic hydrophilic residues (i.e., Asp), while the insoluble fraction contained a high ratio of Gly and Ala (Lowenstam and Weiner, 1989). With the widespread use of molecular biology techniques, more transcripts encoding SMPs were identified (Miyashita et al., 2000; Zhang et al., 2003). In recent years, the mollusc genome project has made great progress (Zhang et al., 2012; Du et al., 2017). Increases the sequence data of SMPs combined with transcriptome and proteome of molluscan mantle and shell have enabled a more thorough investigation into the biomineralization process (Zhang and Zhang, 2006; Politi et al., 2007; Cusack and Freer, 2008; Marin et al., 2008; Furuhashi et al., 2009; Kadar et al., 2009; Marie et al., 2010). For example, the mantle edge of Mytilus galloprovincialis was divided into three regions, and large amounts of differentially abundant transcripts across the three mantle regions were revealed (Bjärnmark et al., 2016). The highly polymorphic genome of the pearl oyster Pinctada fucata martensii, together with transcriptomic and proteomic analyses, allowed the identification of many SMPs (Du et al., 2017). So far, more than 60 different SMPs have been reported (Table 1). In this section, we will discuss the identification and evolution of functional SMPs from the prismatic and nacreous layers of molluscan shells as well as from extrapallial fluid (EPF), and the function of some critical SMPs is highlighted.

\section{SMPs in the Nacreous Layer}

The nacreous layer has attracted most attention for its unique material properties and hierarchical order as well as contribution to the pearl agriculture industry (Jackson et al., 1988; Chateigner et al., 2000; Kono et al., 2000). According to transmission electron microscope (TEM)/SEM observations and $\mathrm{X}$-Ray diffraction (XRD) measurements, the nacreous layer is mainly constituted of aragonite tablets (Marie et al., 2015, 2017). A large number of SMPs involved in the nacreous layer formation have been identified, such as Pif (Suzuki et al., 2009), MSI60 (Sudo et al., 1997), lustrin A (Shen et al., 1997), N16/pearlin (Samata et al., 1999; Miyashita et al., 2000), perlucin, perlustrin (Weiss et al., 2000), N14, N66 (Kono et al., 2000), mucoperlin (Marin et al., 2000), AP7, AP24 (Michenfelder et al., 2003), P10 (Zhang et al., 2006a), perlwapin (Treccani et al., 2006), perlinhibin (Mann et al., 2007), N19 (Yano et al., 2007), N40 (Yan et al., 2007) and blue mussel shell protein (BMSP) (Suzuki et al., 2011). The following paragraphs will introduce pif, a well-studied SMP from the nacreous layer.

Pif, a key macromolecule for nacre formation, is translated into a large precursor and then cleaved into Pif 97 and Pif 80 via posttranslational proteolytic processing (Suzuki et al., 2009). Pif 97, containing a von Willebrand factor type A (VWA) domain, is located at the N-terminal region of the Pif protein, along with the C-terminal Pif 80, which lacks of conserved domains (Burgess and Kelly, 1987; Suzuki et al., 2013). Pif homologs have a wide distribution among various molluscs. The VWA and chitinbinding domains in Pif 97 are highly conserved even among distant species, whereas the sequences of Pif 80 are markedly different (Suzuki et al., 2013; Wang et al., 2013b). Surprisingly, Pif 80's homolog was not detected in Pacific oyster C. gigas (Wang et al., 2013b). The laminin $\mathrm{G}$ domain, a $\mathrm{Ca}^{2+}$-mediated receptor, usually interacts with extracellular matrix proteins (Marin et al., 2008). The $\mathrm{N}$-terminus of the laminin $\mathrm{G}$ domain is present between the chitin-binding domain and the C-terminus of Pif 97, while the $\mathrm{C}$-terminus of the laminin $\mathrm{G}$ is located at the center of Pif 80 , which may contribute to the $\mathrm{CaCO}_{3}$-binding activity of Pif (Suzuki et al., 2013). In C. gigas, the morphology of the 


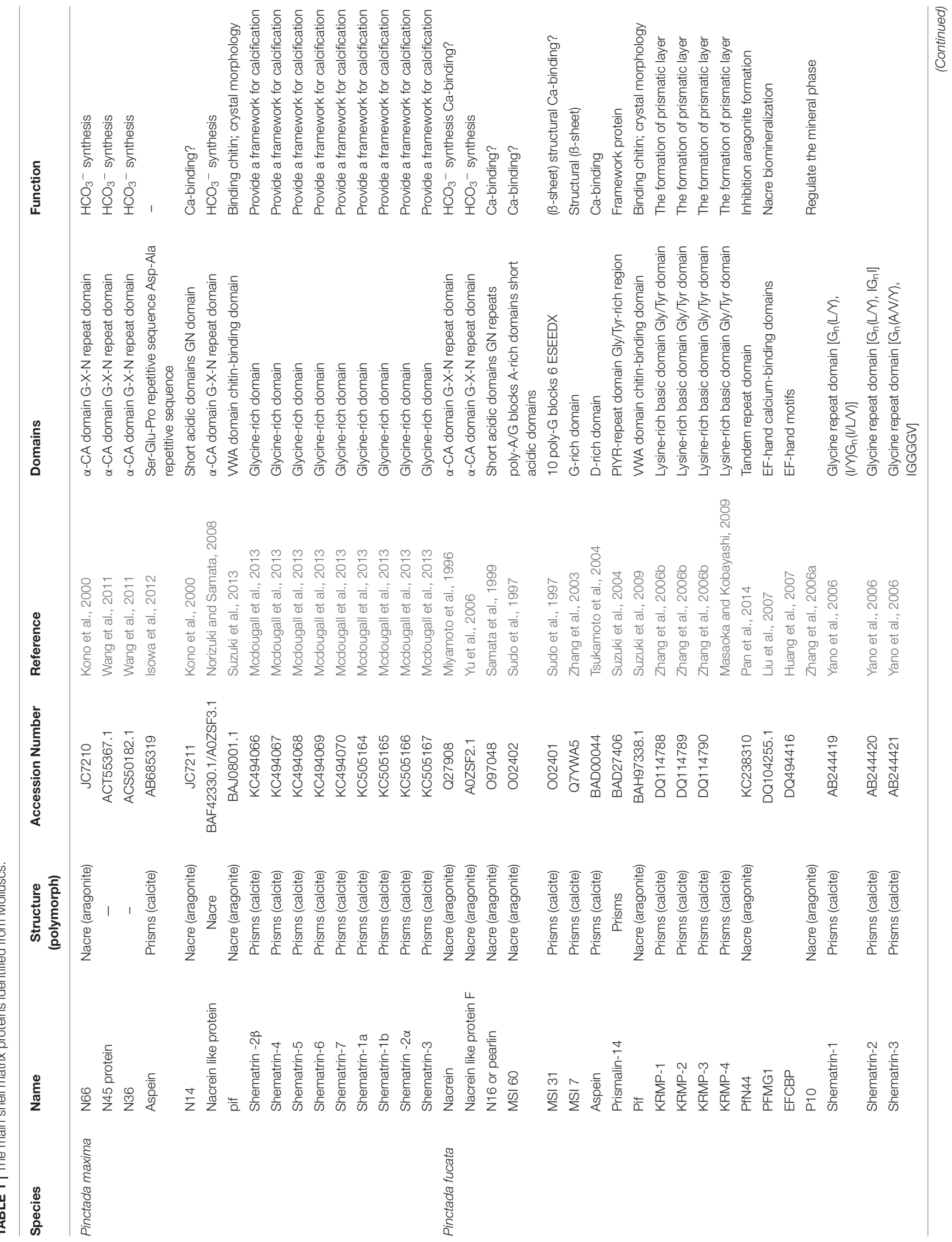




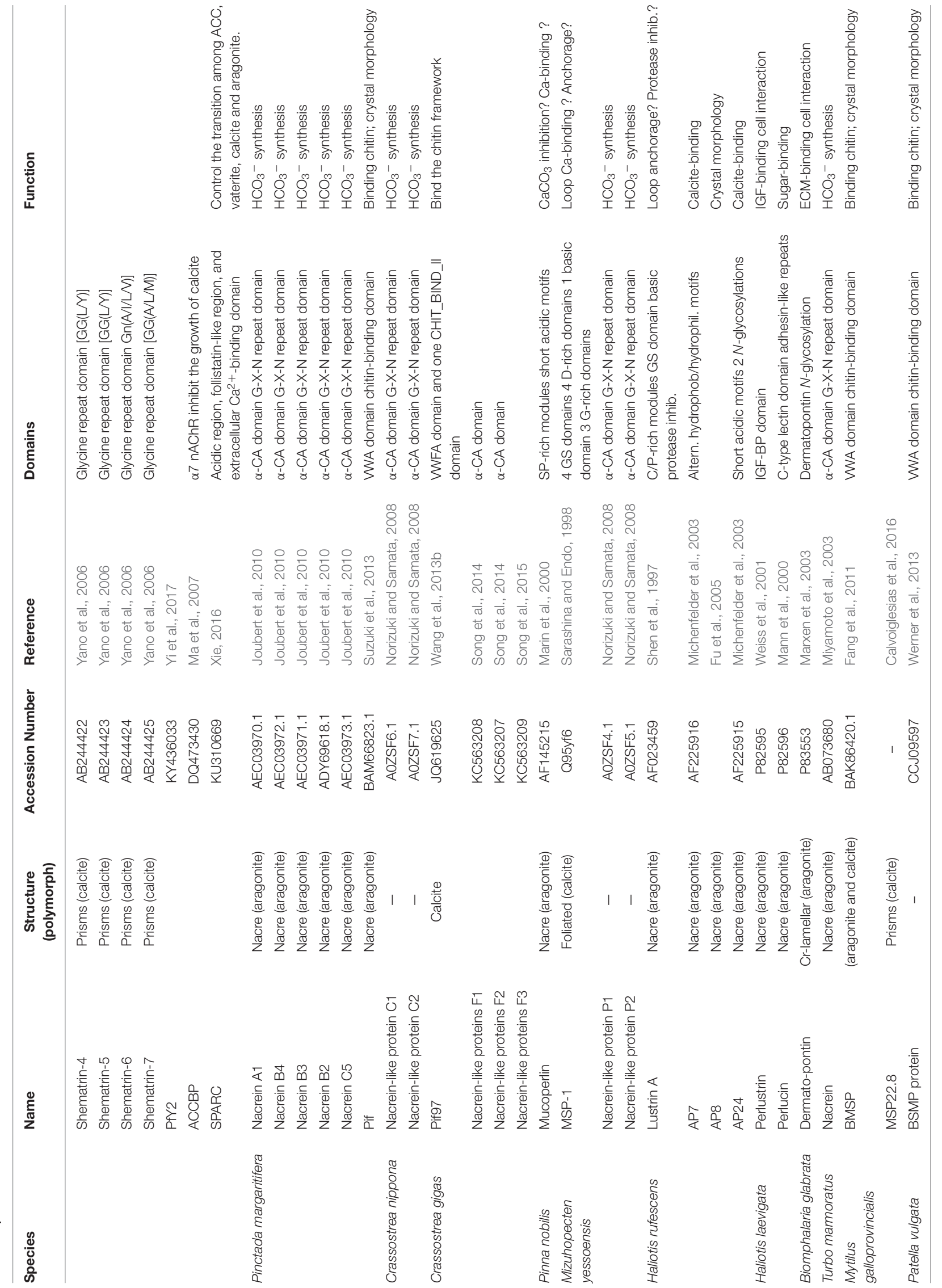




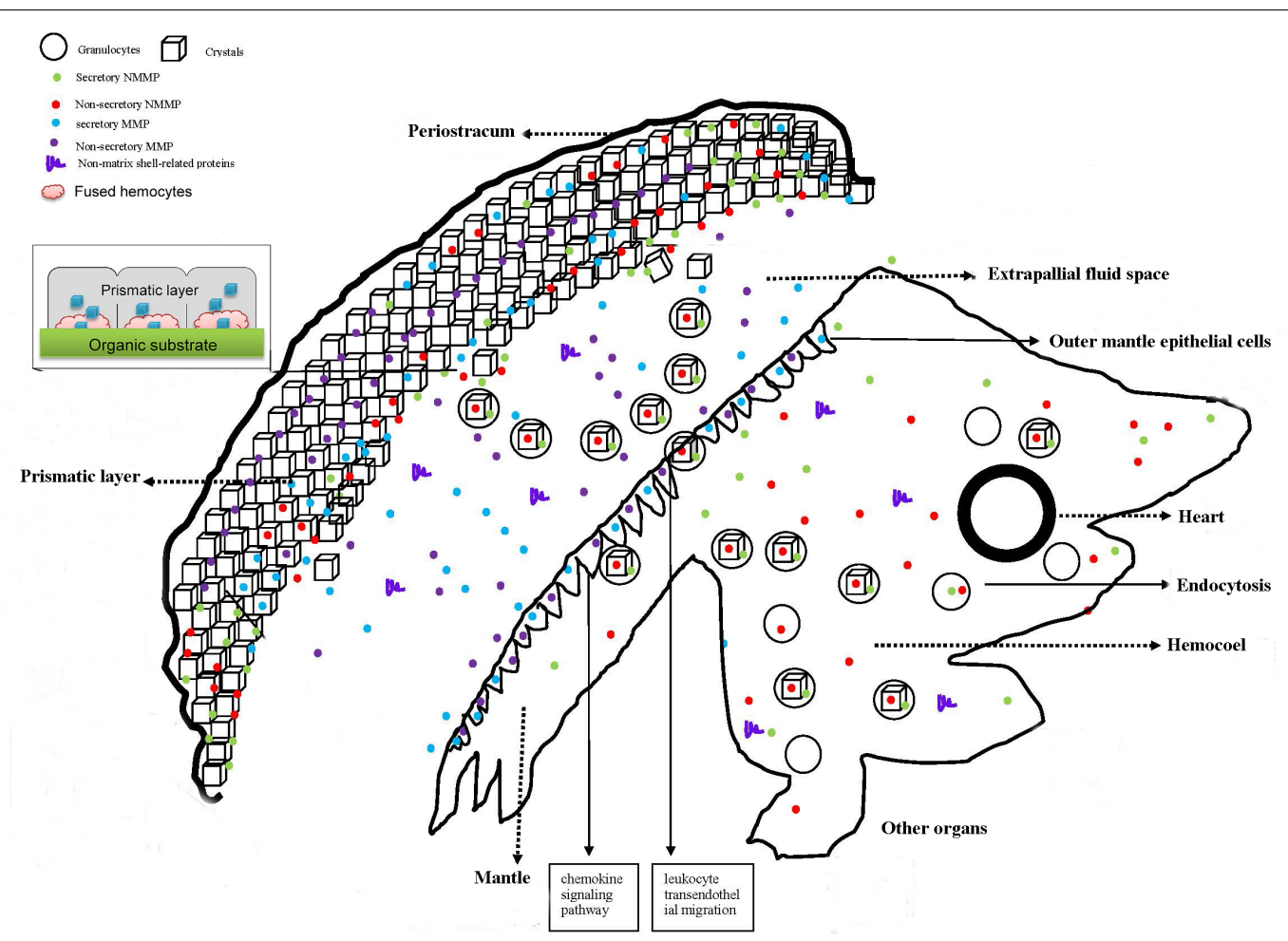

FIGURE 1 | Schematic presentation of shell biomineralization in the oyster (Wang et al., 2013a; Kong et al., 2015; Li et al., 2016). The notes for some of the shapes included in this figure are shown on the upper left. In general, the figure is divided into two parts: soft body and shell. Crystal-bearing hemocytes in the circulating system of oyster are released into the EPF by secretory cavities on the mantle surface and then transported to the biomineralization front. These hemocytes fuse into the prismatic layer columns. They release $\mathrm{CaCO}_{3}$ crystals to form the calcite of the prismatic layers. The fragmented hemocytes assist organic matrices secreted from OMEs to produce the substrate of the prismatic layer. Some shell proteins produced by organs other than the mantle (i.e., the shell proteins not produced by the mantle) may arrive into the hemocoel first and then be engulfed by the granulocytes. The hemocytes and OMEs might be directly involved in the shell regeneration by affixing on the shell regeneration area.

inner shell surface exhibited significant changes after injection of dsRNA of Cg-Pif 97. The calcite laths of the shell became thinner and narrower along with increasing dose of $\mathrm{Cg}$-Pif 97 dsRNA, indicating that the $\mathrm{Cg}$-Pif 97 is indispensable during calcite shell formation in oysters (Wang et al., 2013b). Similarly, the injection of $P f$-Pif dsRNA resulted in disordered growth of the nacreous layer in the pearl oyster $P$. fucata, suggesting that $P f$-Pif might be essential for normal growth of the nacreous layer (Suzuki et al., 2009). Although lacking conserved domains, Pif 80 has some typical structural features, i.e., high proportion of charged and repetitive amino acid residues [17 repeats of AspAsp-Arg (Lys)-Lys (Arg) motif], which contributes to its specific binding ability to the aragonite crystals. In addition, Pif 80 is proposed to be critical in the transformation from inorganic phase to organic mineral during nacre formation. Through strong $\mathrm{Ca}^{2+}$ binding property, recombinant Pif 80 plays crucial roles in transformation from inorganic phase to organic minerals as well as regulation of aragonite crystallization during nacre formation (Bahn et al., 2017). The fraction containing Pif 80, Pif 97, and the N16 complex can induce the formation of aragonite and vaterite crystals in in vitro $\mathrm{CaCO}_{3}$ crystallization experiments, further confirming the essential roles of Pif 80 and Pif 97 during shell formation (Suzuki et al., 2009). Based on above results, the potential function of Pif during aragonite crystal formation is proposed. After first binding to chitin framework, Pif 80 and Pif 97 complex accumulates $\mathrm{CaCO}_{3}$ crystals precipitation inside the chitin membrane, and then regulates them vertical alignment.

Shell matrix proteins are generally classified according to the theoretical isoelectric point (pI). Presently, SMPs associated with nacreous layer formation are classified into two categories: moderately acidic SMPs ( $\mathrm{pI}=4.5-7$, such as pif, MSI60, N16/Pearlin, N14, AP7, AP24 et al.) and basic SMPs ( $\mathrm{pI}=7-10.5$, such as lustrin A, perlucin, perlustrin, perlwapin, perlinhibin, N19, N66 et al.) (Marin et al., 2008). Some SMPs of this category contain a short acidic domain, mainly participating in $\mathrm{Ca}^{2+}$ binding. Besides, other typical domains, such as VWA domain, IGF-BP domain, and C-type lectin domain, usually possess binding function. Thus it is supposed that these SMPs may be related to the extracellular microenvironment, which is critical for shell formation.

\section{SMPs in the Prismatic Layer}

The prismatic layer of mulluscan shell is mainly composed of columnar calcite crystals, which are enclosed in compact organic matrices (Carter, 1985; Chateigner et al., 2000). Lys (K)-rich mantle proteins (KRMPs) (Zhang et al., 2006b), MSI31 
(Sudo et al., 1997), prismalin-14 (Suzuki et al., 2004), aspein (Tsukamoto et al., 2004), prisilkin-39 (Kong et al., 2009), P43 (Gong et al., 2008b), Alv (Kong et al., 2018), and asprich proteins (Gotliv et al., 2005; Politi et al., 2007) have been retrieved from calcitic prism textures and demonstrated to be critical in prismatic layer formation.

KRMPs represent a group of small proteins with a molecular weight of $10 \mathrm{kDa}$, and are unique to pearl oysters (P. fucata, P. maxima and P. margaritifera) (Zhang et al., 2006b; Jackson et al., 2010; Berland et al., 2011; Kinoshita et al., 2011; Mcdougall et al., 2013). KRMPs are typical basic SMPs ( $\mathrm{pI}=9.5-9.8)$ and rich in Lys, Gly and Tyr amino acids (Zhang et al., 2006b). Four KRMP proteins (KRMP-1 to KRMP-4), with 98-101 residues, differ only by few amino acids (Zhang et al., 2006b; Masaoka and Kobayashi, 2009). KRMPs contain two functional domains: a Lysrich basic (BR) domain and a Gly/Tyr-rich (GYR) domain. The BR domain also exists in some other SMPs, i.e., Lustrin A (Shen et al., 1997) and MSP-1 (Sarashina and Endo, 1998), interacting with negatively charged ions or acidic SMPs. The GYR domain exhibits some homology with quinone-tanned proteins, which suggests that the Tyr residues may be oxidized in DOPA in the mature protein. KRMPs are specifically located at the mantle edge, which is recognized as the secretion zone of prismatic layer. The prismatic tablets exhibit irregular morphology after the treatment with dsRNA of KRMP. The surface of prismatic layer become lacunose and the borders between the prisms and the framework are broken along with the increased dosage (Fang et al., 2011). Furthermore, KRMP-3, retrieved from the EDTAinsoluble matrix of the prismatic layer, is located at the organic sheet and the prismatic sheath. Recombinant KRMP-3 binds tightly to chitin via the GYR domain, while the BR domain of KRMP-3 is crucial for inhibition of $\mathrm{CaCO}_{3}$ precipitation and growth of aragonite, as well as regulation of calcite morphology (Liang et al., 2015). Taken together, KRMPs are restricted to pearl oysters as well as their closest relative species, and participate in the framework formation of the prismatic layer.

Prismalin-14, is the first prismatic matrix protein identified at both protein and nucleotide levels (Suzuki et al., 2004). Prismalin-14 contains only 11 types of amino acids with a total length of 105 amino acids. Hydrophobic residues are mostly located at the interzonal region, while hydrophilic residues are distributed at both termini. The structural composition of prismalin-14 is diverse, containing a pyroglutamate, four tandem Pro-Ile-Tyr-Arg (PIYR) repeats, a Gly/Tyr-rich (GY) domain, and two Asp-rich regions at the $\mathrm{N}$ - and the C-termini (Takeuchi et al., 2016). The structure-function relationships of prismalin-14 have been studied through construction of recombinant proteins with different functional domains. Recombinant Prismalin-14 inhibits $\mathrm{CaCO}_{3}$ precipitation in a dose-response (Suzuki and Nagasawa, 2007; Mann et al., 2012). While $\Delta \mathrm{N}$ (including the PIYR repeats, GY-rich, C-terminal regions) shows lower activity and $\Delta \mathrm{N} \Delta \mathrm{C}$ (including the PIYR repeats and GY-rich domain) shows hardly any inhibitory activity at the equal concentration, showing that Asp-rich domains at both termini are inhibitors of $\mathrm{CaCO}_{3}$ precipitation. In addition, the GY-rich domain is indispensable for chitin-binding activity (Suzuki and Nagasawa, 2007). Recently, transcription factor POU3F4 has been shown to directly bind the promoter of prismalin-14, and is essential for its activation function (Jing et al., 2016). Northern blot and in situ hybridization analysis show that Prismalin-14 is selectively and highly expressed at the mantle edge (Suzuki et al., 2004). Taken together, prismalin-14 acts as a scaffold which combines with chitin and $\mathrm{CaCO}_{3}$ crystals in the prismatic layer.

Aspein, the most acidic of all known SMPs ( $\mathrm{pI}=1.45)$, has a high ratio of Asp and is located at the mantle edge (Joubert et al., 2010). It was first identified from the mantle of P. fucata (Tsukamoto et al., 2004), and its homologs have been characterized from several other pterioid species (Isowa et al., 2012). Aspein has a signal peptide sequence (19 amino acids), which is similar to that of Asprich (63\% identity), the acidic shell matrix protein identified from Atrina rigida (Gotliv et al., 2005). The expression levels of Aspein during larval and juvenile stages increase at the onset of calcite formation, while it is also weakly expressed when the shell is only composed of amorphous calcium carbonate (Miyazaki et al., 2010). Aspein especially promotes calcite precipitation via the Asp-rich domain in vitro, indicating its specific function during calcite formation (Takeuchi et al., 2008).

Except for KRMPs, other SMPs involved in prismatic layer formation share a common characteristic, namely, they are enriched in acidic amino acid residues. Thus they usually possess a relatively low pI (i.e., Aspein, pI = 1.67; MSI31, pI = 3.81; Prismalin-14, $\mathrm{pI}=4.16$; $\mathrm{PfN} 44, \mathrm{pI}=4.25)$ and are categorized as extremely acidic SMPs (Marin et al., 2008). The striking finding that acidic proteins are preferentially associated with calcite in molluscan shell, was first reported in M. californianus in 1960s (Hare, 1963), which has been further confirmed with the increasing number of SMPs identified and sequenced (Marin et al., 2008; Liao et al., 2015; Kocot et al., 2016). However, the reason for this intriguing selection remains unknown. Generally, proteins with a high amount of acidic amino acid residues are negatively charged. Thus acidic SMPs should be more liable to bind $\mathrm{Ca}^{2+}$ during shell formation process. Traditionally, acquisition of acidic SMPs is not easy since they are difficult to purify. Nowadays, an increasing number of novel acidic SMPs have been identified and their corresponding primary structures also have been analyzed by virtue of genomic, proteomic and transcriptomic approaches, which will help immensely to reveal the aforementioned phenomenon, such as the preferential choice of acidic proteins associated with calcite in molluscan shell.

\section{SMPs Involved in the Formation of Both Nacreous and Prismatic Layers}

Although outer prisms and inner nacre layers in molluscan shells are assembled from very different protein repertoires, several SMPs, such as Nacrein (Miyamoto et al., 1996), MSI7 (Zhang et al., 2003; Feng et al., 2009), PfY2 (Yi et al., 2017), and shematrins (Yano et al., 2006), have reported to exert dualfunction in both layers.

Nacrein, the first reported molluscan organic SMP, has a carbonic anhydrase (CA)-like domain with an insertion of Gly-X-Asn (G-X-N, X = Asp, Asn, or Glu) or Gly-Asn (G$\mathrm{N})$ repeats, and functions in both nacreous and prismatic layers (Miyamoto et al., 1996, 2005; Miyashita et al., 2002). 
Nacrein homologs have been identified from turban shell Turbo marmoratus (Miyamoto et al., 2003), the edible Iwagaki oyster Crassostrea nippona (Norizuki and Samata, 2008), Yesso scallop Patinopecten yessoensis (Norizuki and Samata, 2008), giant clam Tridacna gigas (Baillie and Yellowlees, 1998; Leggat et al., 2005), Pacific oyster C. gigas (Song et al., 2014), and pearl oyster P. maxima (Kono et al., 2000; Norizuki and Samata, 2008; Wang et al., 2011). The CA-like domains of the nacrein homologues share high similarity with nacrein, while the repeat sequences exhibit variability in length and composition. For example, the composition and length of repeat sequence from T. marmoratus nacrein is markedly different from that of nacrein in P. fucata and P. maxima. The former is composed of G-N two aminoacid repeat with 132 amino acids in length, while the latter is composed of G-X-N three amino-acid repeat with length of 80 amino acids (Miyamoto et al., 2003). The nacre microstructure of gastropods is in column form, whereas in sheet form in bivalves. It is speculated that the structural variance of nacrein may reflect functional difference, which may consequently lead to the production of divergent microstructures (Miyamoto et al., 2003). The structure of nacrein exhibits N-shape via small-angle $\mathrm{X}$-ray scattering, which is consistent with its sequence structural features (Norizuki and Samata, 2008). Nacrein from the pearl oyster $P$. fucata exhibits tissue-specific expression pattern and specifically distributes at the OME (Miyamoto et al., 2005; Gong et al., 2008b). The function of nacrein during shell formation has been further demonstrated. During the in vitro experiments, the addition of recombinant nacrein protein to a saturated solution of $\mathrm{Ca}^{2+}$ and $\mathrm{HCO}_{3}{ }^{-}$, significantly inhibit the precipitation of $\mathrm{CaCO}_{3}$. The deletion of G-X-N repeats of nacrein significantly affects the inhibitory ability to the precipitation of $\mathrm{CaCO}_{3}$ (Miyamoto et al., 2005). Aragonite crystals exhibited aberrant growth, and aragonitic tablets became thickened when nacrein is suppressed by the antibodies (Gong et al., 2008b). It is speculated that nacrein is a negative regulator in aragonitic tablet growth, and the G-X-N or G-N repeat sequence may show inhibitory activity during $\mathrm{CaCO}_{3}$ precipitation (Miyamoto et al., 2005; Norizuki and Samata, 2008).

The novel SMP PfY2 is found in both prisms and nacre layers, suggesting its dual roles in the shell formation of $P$. fucata (Fang et al., 2011). The expression level of PfY2 peaks at $36 \mathrm{~h}$ after shell-notching, indicating its involvement of shell repairing and regenerating process. The recombinant PfY2 can significantly suppress $\mathrm{CaCO}_{3}$ precipitation rate, participate in the crystal nucleation process, and mediate the transition of amorphous $\mathrm{CaCO}_{3}$ to steady calcite or aragonite (Yi et al., 2017). The results clearly demonstrate that PfY2 is a critical macromolecule and performs a variety of biological functions during shell formation.

Shematrins, a family of Gly-rich structural proteins, is comprised of at least nine members with molecular weights of 25 33 kDa (Yano et al., 2006; Mcdougall et al., 2013). With one exception (shematrin-5, $\mathrm{pH}=7.7$ ), all shematrins have a $\mathrm{pI}$ between 9 and 10.3, and are considered as the second family of basic SMPs. They all share characteristic primary structures and exhibit Gly-rich domains, comprised of short motifs of the type $\mathrm{XG}_{\mathrm{n}} \mathrm{X}$ (with $2 \leq \mathrm{n} \leq 6$ and $\mathrm{X}=\mathrm{L} / \mathrm{Y} / \mathrm{A} / \mathrm{V} / \mathrm{I} / \mathrm{M}$ ). All shematrins have a RKKKY, RRKKY or RRRKY motif at the
C-terminal region (Yano et al., 2006). The Gly-rich domain of shematrin-2 is exactly identical to another acidic SMP MSI31 (98\% homology in a 227 residue overlap), but their C-termini are completely different. Shematrin is strongly basic and is supposed to work as a framework for calcification, while MSI31 is extremely acidic and may be involved in nucleating crystals (Sudo et al., 1997). The C-terminal parts of shematrins exhibit a high homology (above $60 \%$ on 26 residues) with the C-terminal Gly-rich region of KRMPs (Zhang et al., 2006a). Shematrin5 is the single protein of the family which contains an acidic domain and is similar to aspein (Tsukamoto et al., 2004). Shematrins exhibit tissue-specific expression and are located at the mantle edge. In addition, shematrin-1, -2, -3, -4, and - 6 are also expressed in mantle pallial layer (Yano et al., 2006), indicating that shematrins possess dual roles in the formation of the nacreous and prismatic layers. Surprisingly, the shematrins are non-detectable in the abalone $H$. asinina, but exhibit active expansion and diversification within the pearl oysters, suggesting the hypothesis that the shell basic toolkit genes evolved rapidly among molluscs (Jackson et al., 2010).

Similar to the SMPs from nacreous layer, SMPs from both layers are either moderately acidic (i.e., nacrein, MSI7,) or basic (i.e., Shematrins). The functions of these SMPs show no difference between the two layers, indicating their important roles during the shell formation process.

\section{SMPs From the Extrapallial Fluid (EPF)}

Extrapallial fluid is an aqueous microenvironment located between the OME and the inner face of shell, and serves as the final medium of nacre calcification (Saha et al., 1988; Lowenstam and Weiner, 1989). EPF contains a variety of ions $\left(\mathrm{Na}^{+}, \mathrm{K}^{+}\right.$, $\mathrm{Ca}^{2+}, \mathrm{Mg}^{2+}, \mathrm{HCO}_{3}{ }^{-}$), whereas the composition of ion content is different from that of the hemolymph and seawater (Saha et al., 1988; Wilt, 2002). EPF also contains various macromolecules secreted by the OME or transported from elsewhere to the EPF, such as proteins, polysaccharides, and lipids, among which the proteins are speculated to perform certain key function during shell biomineralization (Kylmaoja et al., 2016). However, largely due to the difficulty of obtaining EPF, there are few studies on the protein components. Previous studies showed that crude extraction mixtures of EPF proteins have significant influence on the morphology of crystal formation (Yin et al., 2009). Recently, amounts of novel EPF proteins have been identified by liquid chromatography-tandem mass spectrometry (LC-MS/MS) analysis of EPF proteins binding to the $\mathrm{CaCO}_{3}$ crystals (Xie et al., 2016). So far, several SMPs have been extracted from the EPF, such as EP fluid protein from M. edulis (Hattan et al., 2001; Yin et al., 2005), Amorphous calcium carbonate-binding protein (ACCBP) (Ma et al., 2007), Secreted Protein Acidic and Rich in Cysteine (SPARC) from P. fucata (Xie, 2016).

Amorphous calcium carbonate-binding protein (ACCBP) containing an acetylcholine-binding site was the first purified EPF protein from P. fucata (Ma et al., 2007). Size-exclusion Chromatography, chemical cross-linking experiments coupled with negative staining electron microscopy revealed that ACCBP is a decamer composed of two adjacent pentamers, containing two Ca0562-binding sites, which are arranged in a 5-fold 
symmetry. The unique structure is essential for ACC formation and affects the ACC induction efficiency (Su et al., 2013). ACCBP shows inhibitory activity on the growth of calcite and $\mathrm{CaCO}_{3}$ precipitation both in vitro and in vivo (Ma et al., 2007). Besides, ACCBP can identify diverse phases and faces of $\mathrm{CaCO}_{3}$ crystal via acetylcholine-binding site. With this capacity, ACCBP is demonstrated to alter the morphology of nacre lamellae by inhibiting the growth of certain aragonite faces, and simultaneously keep the $\mathrm{CaCO}_{3}$-supersaturated solution in steady-state by terminating the nucleation and growth of calcite (Ma et al., 2007). ACCBP mainly functions as a negative regulator during the shell formation.

Secreted Protein Acidic and Rich in Cysteine (SPARC) contain three typical functional domains (acidic region, follistatin-like region, and extracellular $\mathrm{Ca}^{2+}$-binding domain) and exist in the extracellular matrix of $P$. fucata (Xie, 2016). The expression levels of SPARC in EPF increase after shell-notching in P. fucata, indicating its involvement in shell repair process. SPARC is also found in both nacre and prismatic soluble extracts, and the blocking of SPARC with a polyclonal antibody was shown to inhibit the formation of nacre platelets (Xie, 2016). Furthermore, SPARC regulates the morphology of $\mathrm{CaCO}_{3}$ crystals and induces the formation of vaterite in the calcite crystallization system. However, $\mathrm{Mg}^{2+}$ counteracts this effect and induces the formation of aragonite. Further intrinsic fluorescence and circular dichroism spectrum studies indicate that SPARC may exert function by changing the conformation of its secondary structure. In conclusion, SPARC participates in nacre formation by stabilizing vaterite to inhibit calcite formation via its EC domain and secondary structure variation, as well as by assisting aragonite formation in the presence of $\mathrm{Mg}^{2+}$ or other proteins (Xie, 2016).

Compared with SMPs identified from shell, most EPF proteins perform dual roles during the transition between prism and nacre, which is closely connected with their secondary structures and specific binding capacity to calcite or aragonite. Previous results also suggest that EPF proteins play a critical role in the biomineralization balance process (i.e., shell formation and ablation) (Xie et al., 2016). Remarkably, the amino acid constituents in the EPF proteins inducing aragonite or calcite formation had different preference, which was similar with the SMPs from shell (Hare, 1963; Evans, 2008; Marie et al., 2012; Xie et al., 2016).

\section{The Regulatory Mechanism of SMPs in Molluscs}

In molluscs, their functions of more than 40 SMPs have been elucidated, while the transcriptional regulation mechanisms are poorly studied. So far, only four transcription factors, $P f$-MSX (Zhao et al., 2014), Pf-AP-1 (Zheng et al., 2015), Pf-Rel (Sun et al., 2015), and $P f$-POU3F4 (Jing et al., 2016), have been reported to participate in shell formation through regulating expression of SMPs in molluscs.

$P f$-AP-1, $P f$-MSX, and $P f$-Rel, are homologous genes of MSX, AP-1, and NF- $\mathrm{B}$, which are all involved in bone/tooth formation in vertebrates (Bakiri et al., 2007; Kim et al., 2010;
Saadi et al., 2013). In pearl oyster $P$. fucata, $P f$-AP-1, $P f$-MSX, and $P f$-Rel could directly bind to the promoters of SMPs KRMP, Pearlin, Prisilkin-39, Pif, and nacrein, respectively, and enhances their promoter activities in a dose-dependent manner (Zhao et al., 2014; Sun et al., 2015; Zheng et al., 2015). The mRNA transcripts of KRMP, Pearlin, Prisilkin-39, Pif, and nacrein all exhibited significant depression under the treatment either with inhibitors of AP-1 and NF- $\mathrm{BB}$ or dsRNA of $P f$-MSX and $P f$ Rel (Zhao et al., 2014; Sun et al., 2015; Zheng et al., 2015). Moreover, after injection of Pf-MSX dsRNA, the lamellar sheet from nacreous layer exhibited disorder orientation (Zhao et al., 2014). Similarly, knockdown of $P f$-Rel led to crystal particles on the surface of inner nacreous layer to be scattered and irregular (Sun et al., 2015), which was similar to the morphological changes when Nacrein was blocked by its antibody (Gong et al., 2008b). A putative AP-1 binding site was predicted at the $5^{\prime}$ flanking region of the nacrein gene, and human AP-1(c-jun) has been reported with regulatory function in nacrein transcription in vitro (Miyashita et al., 2012). However in P. fucata, the expression pattern of nacrein showed almost no correlation with $P f$-AP-1, and the inhibitor of AP-1 (SR11302) had no effect on the expression of nacrein (Zheng et al., 2015). In vertebrates, transcription factor POU mainly functions in the neuroendocrine system (Andersen and Rosenfeld, 2001). In molluscs, homolog of POU3F4 (Pf-POU3F4) has been identified and demonstrated to participate in shell formation through binding to the promoters of SMPs Aspein and Prismalin-14, and enhancing their transcriptional activities (Jing et al., 2016).

It is evident that some conservative transcription factors such as AP-1, MSX, and Rel, share similar function among diverse animals, playing important roles in bone/teeth formation in vertebrates and shell formation in molluscs. The distinct functions of POU between mammals and molluscs also suggest that there exist unique features in the regulation mechanism of shell formation in molluscs. So far, most results were obtained from transfection experiments in vitro; more direct evidence within primary culture of molluscan cells will be further highlighted in the future.

\section{The Rapid Evolution of SMPs in Molluscs}

Molluscs began to mineralize at the dawn of the Cambrian times, in a very short time interval, about 544 million years ago (Conway Morris, 2001). Like several other metazoan phyla, molluscs acquired the capacity to form a mineralization exoskeleton far after their emergence as a phylum, implicating that the 'molecular tool box' required for mineralizing is produced and employed. However, the mechanisms underlying production of calcified shell, whether originated from an ancestral biomineralization repertoire, or the production of lateral genetic transfer, are still unclear (Marin et al., 2008). The recent sequencing of several mollusc genomes coupled with the analysis of multi-omics demonstrates that many SMPs evolved independently and the shell proteome may have a much higher plasticity than expected.

The highly complex, robust and patterned shells are diverse among molluscs. Conventionally, the diverse of shell types can best be expressed by the diversity secretory repertoires from outer fold of mantle organ. One might expect that the representative 
characteristics of shell are reflected by evolutionary changes of SMPs. Recent multi-omics studies have revealed the existence of tremendous diversity in the mantle secretomes. For example, a comparative scan between the obtained EST sequences of the abalone $H$. asinina and the genome of the patellogastropod Lottia scutum, shows that only $19 \%$ of the secreted proteins of $H$. asinina have their homologues in L. scutum (Jackson et al., 2006). Less than $15 \%$ of the secreted proteins are shared between a bivalve ( $P$. maxima) and a gastropod (H. asinina), by comparing their nacre-secreting mantle transcriptomes (Jackson et al., 2010). In addition, a large proportion of novel secreted proteins are identified in the shell proteomes of L. gigantea when searched in the public databases. Few homologous proteins (1.1 to $7.7 \%$ ) are found between any two molluscan species (Marie et al., 2013). Interestingly, the number of homologous SMPs shared between different classes is more than that between the same class, based on the comparison of the mantle transcriptomic of L. gigantea, P maxima, and H. asinina (Jackson et al., 2010). In addition, SMP genes are reported to be frequently duplicated in the Pinctada and Lottia genome (Marie et al., 2013; Takeuchi et al., 2016). For example, five genes of the shematrins tandemly cluster in two scaffolds. Three and two transcripts of N19 and N16 locate at same scaffold, respectively. Amazingly, homologous to shematrin, N19 and N16 are not detected in the C. gigas genome (Miyamoto et al., 2013; Takeuchi et al., 2016). Thus it could be concluded that these SMP genes are unique to the $P$. fucata lineage, and duplication occurred after speciation.

The acid-insoluble matrices (AIMs) associated with prismatic and nacreous layers are extremely different. Prism AIM is rich in Tyr, Pro, and Val, while nacre AIM contains more Ala and Asx (Asn and Asp). Eighty different SMPs have been identified between prismatic and nacreous layer, among which 64 are entirely unique (Marie et al., 2012). In Pinctada spp., 47/50 prism-related proteins are restricted to prisms, while 30/33 nacre-related proteins, are unique to nacre. A high ratio of the analyzed 61 transcripts were selectively overexpressed at the edge or pallium cells of the mantle organ, which is in line with the protein distribution either in prism or in nacre (Marie et al., 2012). Homologs of aragonite-and calcite-associated SMPs were searched through the oyster genome. Surprisingly, homologs of calcite-associated SMPs were non-detectable (0/29), while nine homologs of aragonite-associated SMPs are identified in the oyster genome (9/28). Since the oyster shell mainly is composed of calcite crystal, only the zone of the adductor muscle scar is composed of aragonite (Lee et al., 2011). Thus, aragonite-associated SMPs may be more conserved than the calcite-associated SMPs in the Molluscs.

Repetitive, low-complexity domains (RLCDs), in particular Gly-rich structural proteins, usually existed in tough, extracellular structures, and also have been identified in molluscan shell, such as KRMP (Masaoka and Kobayashi, 2009) and shematrin (Yano et al., 2006). Previous studies suggest that KRMPs and shematrins have large paralogous genes (at least 11 KRMPs, and 9 shematrins) in Pinctada spp., but show significant sequence divergence among orthologous genes, supporting the hypothesis that many SMPs are rapidly evolving (Yano et al., 2006; Masaoka and Kobayashi, 2009). RLCDs usually function in structure construction, and appear to evolve rapidly under selective pressures through Metazoans (Smith-Keune and Jerry, 2009). Therefore, it is proposed that the rapid evolution of KRMPs and shematrins probably arise from the RLCDs, which usually endow new mechanical properties with the structure they comprise (Jackson et al., 2010; Mcdougall et al., 2013).

The recent availability of complete genome data for several molluscs (Zhang et al., 2012; Takeuchi et al., 2016; Du et al., 2017; Nam et al., 2017; Wang et al., 2017), and the vastly increasing transcriptome, proteome, and secretome data, enable identification of more novel SMPs, and to comparatively study the origin and evolution of biomineralization in molluscs. Existing results reveal that SMPs are divergent in different molluscs, consistent with the heterogeneity of shell microstructures, which is constructed from a rapidly evolving secretome and has evolved convergent. However, since lack of steady cell line, the functions and transcription regulation of most SMPs have been investigated using in vivo experiments, which cannot truly reflect the interaction among SMPs under physiological conditions. More insight into the true functions of SMPs should be obtained either via in vitro cell culture system from molluscs or in vivo reverse genetics, such as RNAi or CRISPR/Cas9 genome editing technique.

\section{Hemocyte-Mediated Shell Mineralization in Molluscs}

Hemocytes are essential during the innate immune response, which has been shown to be related to biomineralization in molluscs. For example, amounts of hemocytes accumulate in the pearl sac after transplantation in pearl oyster (Kishore and Southgate, 2015). Immune-associated genes also exhibit significant expression during the shell regeneration period in Laternula elliptica (Sleight et al., 2015). Recently, more evidence directly demonstrated that hemocytes (mainly granulocytes) participate in the synthesis and delivery of $\mathrm{CaCO}_{3}$ crystals as well as SMPs during the shell regeneration process (Mount et al., 2004; Mount and Pickering, 2009; Cho and Jeong, 2011; Johnstone et al., 2015; Li et al., 2016).

Shell damage-repair is a routine method to study shell formation. During shell regeneration, granulocytes have been shown to participate in the synthesis and transportation of $\mathrm{CaCO}_{3}$ (Mount et al., 2004; Johnstone et al., 2015). The granular inclusions of hemocytes are $\mathrm{Ca}^{2+}$-positive in the green ormer H. tuberculata (Fleury et al., 2008), Pacific oyster C. gigas (Ivanina et al., 2017), deep-sea mussel Bathymodiolus azoricus (Kadar et al., 2009), and pearl oyster P. fucata (Li et al., 2016), suggesting that the granulocytes may be a calcium pool and act as a calcium conveyor during shell formation (Kadar et al., 2009; Cho and Jeong, 2011). Intracellular $\mathrm{CaCO}_{3}$ crystals are observed in hemocytes of various shelled molluscs. For example, x-ray microanalysis (SEM-EDS) reveals that crystal-shaped inclusions with rhombohedral appearance are enclosed in the refractive granulocytes (REF granulocytes), a subclass of granulocytes in Eastern oyster C. virginica. Some REF granulocytes have only one or two crystals, while others have numerous (Mount et al., 2004). Crystal-like structures with various shapes are also observed in 
granulocytes of $P$. fucata, but one crystal could be only found in one cell. The chemical components of crystal-like structures were analyzed via SEM-EDS, which mainly contain $\mathrm{Ca}, \mathrm{C}, \mathrm{O}_{2}$, $\mathrm{P}$, and $\mathrm{Si}$, similar to natural $\mathrm{CaCO}_{3}$ crystals (Li et al., 2016). There are varied shapes of the crystals in P. fucata, but only hexahedron crystals are observed in C. virginica. Furthermore, REF cells are present on the prismatic shell surface in lines with fibrous materials and crystals (Mount et al., 2004). Similarly, the granulocytes are embedded into the column and fragmentation of matured shell, which was observed in oyster C. gigas (Cho and Jeong, 2011) and P. fucata (Li et al., 2016), directly showing that living hemocytes are present at the mineralization front. In addition, a highly refractive structure is detected in the hemocytes of B. azoricus induced by shell damage (Kádár, 2008), and insoluble $\mathrm{CaCO}_{3}$ is synthesized in the hemocytes of Venerupis philippinarum during the initial period of shell regeneration (Trinkler et al., 2011). The crystal bearing hemocytes present in the EPF of the oyster $C$. virginica and the mussel $B$. azoricus, are able to start $\mathrm{CaCO}_{3}$ crystal nucleation in vivo (Kadar et al., 2009; Cho et al., 2011). Remarkably, after incubation with EPF mixture, the hemocytes in Pacific oyster C. gigas produce numerous spherical calcium granules, which are almost identical in morphology and chemistry to those on the regenerated shell, suggesting the involvement of hemocytes during the regeneration of prismatic layer (Cho and Jeong, 2011). Given that the prismatic layer locates outside the calcified shell and is first produced during biomineralization, the granulocytes may participate in the initiating process of shell biomineralization. The involvement of hemocytes in the nacreous layer formation remains concern.

Besides to crystal synthesis and transport, the hemocytes are reported to function in the organic framework formation. Multiomics data reveal that various SMPs are highly expressed in the hemocytes of various shelled molluscs. For example, SMPs (e.g., Shematrin 2 and ACCBP) and $\mathrm{Ca}^{2+}$ binding proteins $\alpha$-subunit are abundant in the hemocytes of $P$. fucata (Liao et al., 2015; Li et al., 2016). In the Pacific oyster C. gigas, several shell formation related genes, i.e., chitin synthases, nacreinlike protein, casein kinases, VEGF and VEGF-R, are highly expressed in $\mathrm{H} 2$ and $\mathrm{H} 3$ hemocytes (kinds of larger, irregularly shaped cells, similar to granulocytes), which are potential players in biomineralization processes (Ivanina et al., 2017). SMPs were visualized in molluscan hemocytes during the shell repair process, suggesting the contribution of hemocytes to the formation of the shell framework (Shitalbahen, 2004; Johnstone et al., 2008). For example, SMP coated with collagen fibers were secreted from hemocytes of the Eastern oyster, C. virginica during the shell repair process (Shitalbahen, 2004). A $48 \mathrm{kDa}$ SMP has been localized in hemocytes, but is unobservable after induction of shell repair (Johnstone et al., 2008). It is reported that circulating hemocytes can internalize the antigen when exposed to a hemocyte-free EPF liquid (Calvoiglesias et al., 2016). Due to limited knowledge, the specific function of hemocytes during the secretion and transportation of SMPs needs further investigation.

In conclusion, there is a suitable microenvironment in hemocytes of molluscs for depositing $\mathrm{CaCO}_{3}$ crystal. Hemocytes might play crucial roles during shell formation by regulating the in vivo formation of $\mathrm{CaCO}_{3}$ crystals, transferring the crystals via the EPF to the regenerated prismatic layer, assisting SMPs to form crystal template. The hemocyte might function in immune response with the similar role during soft tissue repair. More focus of the hemocytes function during the larvae ontogenesis, the demineralization, abnormal biomineralization as well as nacreous layer formation, would be helpful to investigate the hemocyte-mediated shell mineralization in molluscs.

\section{THE POTENTIAL CELLULAR MODEL AND MECHANISM OF SHELL BIOMINERALIZATION}

The mechanisms of shell formation have been investigated over the past several decades. Calcite and aragonite are two common polymorphs in molluscan shell structure, which mainly differ in the organization and orientation of the carbonate molecules (Stenzel, 1963). Hare (1963) indicated the composition difference of organic matrices in aragonite and calcite, and thus proposed that the organic matrix proteins might be responsible for the formation of various shell structures and mineral phases. It was reported that the addition of excessive $\mathrm{Mg}^{2+}$ $(400 \mathrm{mg} / 500 \mathrm{ml})$ promotes the accumulation of aragonite in $\mathrm{CaCO}_{3}$ solutions during in vitro experiments (Tokuyama, 1969), suggesting that the concentration of ions (in particular $\mathrm{Mg}^{2+}$ ) in the precipitating solution could regulate the polymorphism between aragonite-calcite in molluscan shell (Blackwelder et al., 1976; Wilbur and Bernhardt, 1984). In order to determine the significance of organic matrices, especially the proteins that function in shell formation, Falini et al. (1996) reassembled a substrate in vitro composed of $\beta$-chitin and silk fibroin for crystal nucleation. They found that proteins extracted from the aragonitic- and calcitic- shell layers could mainly induce aragonite and calcite formation in vitro, respectively (Falini et al., 1996). A large number of subsequent studies support the matrix-mediated shell formation hypothesis, and it has been widely believed that shell calcification occurs in mantle-secreted compartments of chitin, silk fibroin and matrix proteins, and the matrix proteins are associated with the mineral phase and influence on crystal growth (Watabe, 1965; Addadi et al., 2006; Furuhashi et al., 2009). The first observation of hemocytes at the mineralization front using vital fluorescent staining and SEM raised the cellular basis for shell formation (Mount et al., 2004). Secretome and transcriptome data reveal that some SMPs are non-secretory, and some others were abundant in other tissues (Marie et al., 2010, 2012; Kinoshita et al., 2011; Mann et al., 2012; Wang et al., 2013a). Furthermore, biominerals and SMPs are observed in the hemocytes (Johnstone et al., 2008; Calvoiglesias et al., 2016), and hemocytes as well as OME assembling on the surface of regenerated prismatic layer (Cho and Jeong, 2011; Johnstone et al., 2015; Kong et al., 2015), prompt us to investigate the mechanism of shell formation from cellular aspects. The hypothesis that co-operative interaction of hemocytes and OME during shell formation have been developed (Figure 1).

Most SMPs are produced and secreted by the OME, while a few SMPs are produced from hemocytes or other organs 
(Miyamoto et al., 2013; Wang et al., 2013a). The SMPs produced by the OME will be directly delivered to the crystallization surface via exosome (Zhang et al., 2012) or classical secretory pathway, while those produced from other organs are first transported to the hemolymph via classical or non-classical secretory pathways (Gardella et al., 2002), then engulfed by hemocytes (mainly granulocytes). The $\mathrm{CaCO}_{3}$ crystal either produced in the mantle or synthesized in hemocytes (granulocytes) will be delivered to the biomineralization front via the EPF (Mount et al., 2004; Weiner and Addadi, 2011; Li et al., 2016). The organic matrix or mucus secreted from OME can load with $\mathrm{Ca}^{2+}$ and deliver them to the biomineralization front via the EPF (Fleury et al., 2008; Kadar et al., 2009). During the shell regeneration process, the granulocytes are embedded into the columns of the prismatic layer, and interact with SMPs, or with polysaccharide or chitin, to construct the shell framework. $\mathrm{CaCO}_{3}$ crystals discharged from hemocytes (granulocytes), organic matrix or mucus, are subsequently deposited on the calcite of the prismatic layer (Wang et al., 2013a; Li et al., 2016).

\section{CONCLUDING REMARKS}

Biomineralization occurs widely in nature, and the shell formation of molluscs is considered as a good model of this process. The molluscan shells are produced under a series of sophisticated regulation steps involving cells (OME and hemocytes) and cell products (macromolecules mainly including SMPs, chitin and silk fibroin). The coordination between them reveals the cellular and molecular mechanism of biologically controlled mineralization. Multi-omics analyses together with molecular biology techniques has unveiled novel findings, i.e.,

\section{REFERENCES}

Addadi, L., Joester, D., Nudelman, F., and Weiner, S. (2006). Mollusk shell formation: a source of new concepts for understanding biomineralization processes. Chemistry 12, 980-987. doi: 10.1002/chem.200500980

Addadi, L., Moradian, J., Shay, E., Maroudas, N. G., and Weiner, S. (1987). A chemical model for the cooperation of sulfates and carboxylates in calcite crystal nucleation: relevance to biomineralization. Proc. Natl. Acad. Sci. U.S.A. 84, 2732-2736. doi: 10.1073/pnas.84.9.2732

Albeck, S., Aizenberg, J., Addadi, L., and Weiner, S. (1993). Interactions of various skeletal intracrystalline components with calcite crystals. J. Am. Chem. Soc. 115, 11691-11697. doi: 10.1021/ja00078a005

Andersen, B., and Rosenfeld, M. G. (2001). POU domain factors in the neuroendocrine system: lessons from developmental biology provide insights into human disease. Endocr. Rev. 22, 2-35. doi: 10.1210/er.22.1.2

Bahn, S. Y., Jo, B. H., Choi, Y. S., and Cha, H. J. (2017). Control of nacre biomineralization by Pif80 in pearl oyster. Sci. Adv. 3:e1700765. doi: 10.1126/ sciadv. 1700765

Baillie, B. K., and Yellowlees, D. (1998). Characterization and function of carbonic anhydrases in the zooxanthellae-giant clam symbiosis. Proc. Biol. Sci. 265, 465-473. doi: 10.1098/rspb.1998.0318

Bakiri, L., Takada, Y., Radolf, M., Eferl, R., Yaniv, M., Wagner, E. F., et al. (2007). Role of heterodimerization of c-Fos and Fral proteins in osteoclast differentiation. Bone 40, 867-875. doi: 10.1016/j.bone.2006.11.005

Berland, S., Marie, A., Duplat, D., Milet, C., Sire, J. Y., and Bédouet, L. (2011). Coupling proteomics and transcriptomics for the identification of novel and variant forms of mollusk shell proteins: a study with P. margaritifera. Chembiochem 12, 950-961. doi: 10.1002/cbic.201000667 the diversity of SMPs and significant variation between different SMP repertoires, the multiple-organ origin of SMPs, and the involvement of hemocytes in the formation of prismatic layer. These findings illustrate the complicated processes during shell formation, which will prompt a more detailed investigation on biomineralization in molluscan shell. Recent research have found that shell extracts from M. edulis and C. gigas promote the catabolic pathway of primarily cultured human dermal fibroblasts, which might be helpful in the context of anti-fibrotic strategies, particularly against scleroderma. Future studies in shell formation of molluscs are likely to uncover potential links to immunity as well as human disease, thus revealing a better understanding of the evolution of biomineralization.

\section{AUTHOR CONTRIBUTIONS}

XS and ZL collected the literature and prepared the manuscript. LW and LS revised the manuscript. LS designed the manuscript.

\section{FUNDING}

The work is supported by a grant (No. U1706204) from National Science Foundation of China, and earmarked fund (CARS49) from Modern Agro-industry Technology Research System, AoShan Talents Cultivation Program Supported by Qingdao National Laboratory for Marine Science and Technology (No. 2017ASTCP-OS13), Key R\&D Program of Liaoning Province (201703165), and the Fund for Outstanding Talents and Innovative Team of Agricultural Scientific Research.

Bigatti, G., Giraudbilloud, M., Vega, I. A., Penchaszadeh, P. E., and Castrovazquez, A. (2010). The calcareous egg capsule of the Patagonian neogastropod Odontocymbiola magellanica: morphology, secretion and mineralogy. J. Molluscan Stud. 76, 279-288. doi: 10.1093/mollus/eyq006

Bjärnmark, N. A., Yarra, T., Churcher, A. M., Felix, R. C., Clark, M. S., and Power, D. M. (2016). Transcriptomics provides insight into Mytilus galloprovincialis (Mollusca: Bivalvia) mantle function and its role in biomineralisation. Mar. Genomics 27, 37-45. doi: 10.1016/j.margen.2016.03.004

Blackwelder, P. L., Weiss, R. E., and Wilbur, K. M. (1976). Effects of calcium, strontium, and magnesium on the coccolithophorid Cricosphaera (Hymenomonas) carterae. I. Calcification. Mar. Biol. 34, 11-16. doi: 10.1007/ BF00390781

Burgess, T. L., and Kelly, R. B. (1987). Constitutive and regulated secretion of proteins. Annu. Rev. Cell Biol. 3, 243-293. doi: 10.1146/annurev.cb.03.110187. 001331

Calvoiglesias, J., Pérezestévez, D., Lorenzoabalde, S., Sánchezcorrea, B., Quiroga, M. I., and Fuentes, J. M. (2016). Characterization of a monoclonal antibody directed against Mytilus spp larvae reveals an antigen involved in shell biomineralization. PLoS One 11:e0152210. doi: 10.1371/journal.pone. 0152210

Carter, J. (1985). Classification and phylogenetic significance of molluscan shell microstructure. Mollusks 13, 50-71.

Chateigner, D., Hedegaard, C., and Wenk, H.-R. (2000). Mollusc shell microstructures and crystallographic textures. J. Struct. Geol. 22, 1723-1735. doi: 10.1016/S0191-8141(00)00088-2

Cho, S. M., and Jeong, W. G. (2011). Prismatic shell repairs by hemoctyes in the extrapallial fluid of the Pacific Oyster, Crassostrea gigas. Korean J. Malacol. 27, 223-228. doi: 10.9710/kjm.2011.27.3.223 
Cho, S. M., Lee, Y. M., and Jeong, W. G. (2011). Effect of polycyclic aromatic hydrocarbon (PAH) on shell repair in the pacific oyster, Crassostrea gigas. Korean J. Malacol. 27, 35-42. doi: 10.9710/kjm.2011.27.1.035

Conway Morris, S. (2001). "Significance of early shells," in Palaeobiology II, eds P. R. Crowther and D. Briggs (Oxford: Blackwell Science), 31-40. doi: 10.1002/ 9780470999295.ch6

Cusack, M., and Freer, A. (2008). Biomineralization: elemental and organic influence in carbonate systems. Chem. Rev. 108, 4433-4454. doi: 10.1021/ cr078270o

Du, X., Fan, G., Jiao, Y., Zhang, H., Guo, X., Huang, R., et al. (2017). The pearl oyster Pinctada fucata martensii genome and multi-omic analyses provide insights into biomineralization. Gigascience 6, 1-12. doi: 10.1093/gigascience/ gix059

Evans, J. S. (2008). "Tuning in" to mollusk shell nacre- and prismatic-associated protein terminal sequences. Implications for biomineralization and the construction of high performance inorganic-organic composites. Chem. Rev. 108, 4455-4462. doi: 10.1021/cr078251e

Falini, G., Albeck, S., Weiner, S., and Addadi, L. (1996). Control of aragonite or calcite polymorphism by mollusk shell macromolecules. Science 271, 67-69. doi: 10.1126/science.271.5245.67

Fang, D., Xu, G., Hu, Y., Pan, C., Xie, L., and Zhang, R. (2011). Identification of genes directly involved in shell formation and their functions in pearl oyster, Pinctada fucata. PLoS One 6:e21860. doi: 10.1371/journal.pone.0021860

Feng, Q., Fang, Z., Yan, Z., Xing, R., Xie, L., and Zhang, R. (2009). The structurefunction relationship of MSI7, a matrix protein from pearl oyster Pinctada fucata. Acta Biochim. Biophys. Sin. 41, 955-962. doi: 10.1093/abbs/gmp086

Fleury, C., Marin, F., Marie, B., Luquet, G., Thomas, J., Josse, C., et al. (2008). Shell repair process in the green ormer Haliotis tuberculata: a histological and microstructural study. Tissue Cell 40, 207-218. doi: 10.1016/j.tice.2007.12.002

Fu, G., Valiyaveettil, S., Wopenka, B., and Morse, D. E. (2005). CaCO3 biomineralization: acidic 8 - $\mathrm{kDa}$ proteins isolated from aragonitic abalone shell nacre can specifically modify calcite crystal morphology. Biomacromolecules 6 , 1289-1298. doi: 10.1021/bm049314v

Furuhashi, T., Schwarzinger, C., Miksik, I., Smrz, M., and Beran, A. (2009). Molluscan shell evolution with review of shell calcification hypothesis. Comp. Biochem. Physiol. B Biochem. Mol. Biol. 154, 351-371. doi: 10.1016/j.cbpb.2009. 07.011

Galante-Oliveira, S., Marcal, R., Guimaraes, F., Soares, J., Lopes, J. C., Machado, J., et al. (2014). Crystallinity and microchemistry of Nassarius reticulatus (Caenogastropoda) statoliths: towards their structure stability and homogeneity. J. Struct. Biol. 186, 292-301. doi: 10.1016/j.jsb.2014.03.023

Gardella, S., Andrei, C., Ferrera, D., Lotti, L. V., Torrisi, M. R., Bianchi, M. E., et al. (2002). The nuclear protein HMGB1 is secreted by monocytes via a non-classical, vesicle-mediated secretory pathway. EMBO Rep. 3, 995-1001. doi: 10.1093/embo-reports/kvf198

Gong, N., Ma, Z., Li, Q., Li, Q., Yan, Z., Xie, L., et al. (2008a). Characterization of calcium deposition and shell matrix protein secretion in primary mantle tissue culture from the marine pearl oyster Pinctada fucata. Mar. Biotechnol. 10, 457-465. doi: 10.1007/s10126-008-9081-1

Gong, N., Shangguan, J., Liu, X., Yan, Z., Ma, Z., Xie, L., et al. (2008b). Immunolocalization of matrix proteins in nacre lamellae and their in vivo effects on aragonitic tablet growth. J. Struct. Biol. 164, 33-40. doi: 10.1016/j. jsb.2008.05.009

Gotliv, B. A., Kessler, N., Sumerel, J. L., Morse, D. E., Tuross, N., Addadi, L., et al. (2005). Asprich: a novel aspartic acid-rich protein family from the prismatic shell matrix of the bivalve Atrina rigida. Chembiochem 6, 304-314. doi: 10.1002/ cbic. 200400221

Hare, P. E. (1963). Amino acids in the proteins from aragonite and calcite in the shells of Mytilus californianus. Science 139, 216-217. doi: 10.1126/science.139. 3551.216

Hashimoto, N., Kurita, Y., and Wada, H. (2012). Developmental role of dpp in the gastropod shell plate and co-option of the dpp signaling pathway in the evolution of the operculum. Dev. Biol. 366, 367-373. doi: 10.1016/j.ydbio.2012. 04.010

Hattan, S. J., Laue, T. M., and Chasteen, N. D. (2001). Purification and characterization of a novel calcium-binding protein from the extrapallial fluid of the mollusc, Mytilus edulis. J. Biol. Chem. 276, 4461-4468. doi: 10.1074/jbc. M006803200
Howard, B., Mitchell, P. C., Ritchie, A., Simkiss, K., and Taylor, M. (1981). The composition of intracellular granules from the metal-accumulating cells of the common garden snail (Helix aspersa). Biochem. J. 194, 507-511. doi: 10.1042/ bj1940507

Huang, J., Zhang, C., Ma, Z., Xie, L., and Zhang, R. (2007). A novel extracellular EFhand protein involved in the shell formation of pearl oyster. Biochim. Biophys. Acta 1770, 1037-1044. doi: 10.1016/j.bbagen.2007.03.006

Islam, T., and Peng, C. (2018). Morphological and cellular diversity of magnetotactic bacteria: a review. J. Basic Microbiol. 58, 378-389. doi: 10.1002/ jobm. 201700383

Isowa, Y., Sarashina, I., Setiamarga, D. H., and Endo, K. (2012). A comparative study of the shell matrix protein aspein in pterioid bivalves. J. Mol. Evol. 75, 11-18. doi: 10.1007/s00239-012-9514-3

Ivanina, A. V., Falfushynska, H. I., Beniash, E., Piontkivska, H., and Sokolova, I. M. (2017). Biomineralization-related specialization of hemocytes and mantle tissues of the Pacific oysters Crassostrea gigas. J. Exp. Biol. 220(Pt 18), 32093221. doi: $10.1242 /$ jeb.160861

Jackson, A., Vincent, J., and Turner, R. (1988). The mechanical design of nacre. Proc. R. Soc. Lond. Ser. B Biol. Sci. 234, 415-440.

Jackson, D. J., McDougall, C., Green, K., Simpson, F., Wörheide, G., and Degnan, B. M. (2006). A rapidly evolving secretome builds and patterns a sea shell. $B M C$ Biol. 4:40. doi: 10.1186/1741-7007-4-40

Jackson, D. J., Mcdougall, C., Woodcroft, B., Moase, P., Rose, R. A., Kube, M., et al. (2010). Parallel evolution of nacre building gene sets in molluscs. Mol. Biol. Evol. 27, 591-608. doi: 10.1093/molbev/msp278

Jing, G., Yan, C., Yi, Y., Jian, L., Xie, J., Liu, J., et al. (2016). The transcription factor Pf-POU3F4 regulates expression of the matrix protein genes Aspein and Prismalin-14 in pearl oyster (Pinctada fucata). FEBS J. 283, 1962-1978. doi: 10.1111/febs.13716

Johnstone, M. B., Ellis, S., and Mount, A. S. (2008). Visualization of shell matrix proteins in hemocytes and tissues of the Eastern oyster, Crassostrea virginica. J. Exp. Zool. B Mol. Dev. Evol. 310, 227-239. doi: 10.1002/jez.b.21206

Johnstone, M. B., Gohad, N. V., Falwell, E. P., Hansen, D. C., Hansen, K. M., and Mount, A. S. (2015). Cellular orchestrated biomineralization of crystalline composites on implant surfaces by the eastern oyster, Crassostrea virginica (Gmelin, 1791). J. Exp. Mar. Biol. Ecol. 463, 8-16. doi: 10.1016/j.jembe.2014. 10.014

Joubert, C., Piquemal, D., Marie, B., Manchon, L., Pierrat, F., Zanella-Cléon, I., et al. (2010). Transcriptome and proteome analysis of Pinctada margaritifera calcifying mantle and shell: focus on biomineralization. BMC Genomics 11:613. doi: 10.1186/1471-2164-11-613

Kádár, E. (2008). Haemocyte response associated with induction of shell regeneration in the deep-sea vent mussel Bathymodiolus azoricus (Bivalvia: Mytilidae). J. Exp. Mar. Biol. Ecol. 362, 71-78. doi: 10.1016/j.jembe.2008.05.014

Kadar, E., Lobo-Da-Cunha, A., and Azevedo, C. (2009). Mantle-to-shell CaCO3 transfer during shell repair at different hydrostatic pressures in the deepsea vent mussel Bathymodiolus azoricus (Bivalvia: Mytilidae). Mar. Biol. 156, 959-967. doi: 10.1007/s00227-009-1140-2

Kim, K., Kim, J. H., Youn, B. U., Jin, H. M., and Kim, N. (2010). Pim-1 regulates RANKL-induced osteoclastogenesis via NF-kappaB activation and NFATc1 induction. J. Immunol. 185, 7460-7466. doi: 10.4049/jimmunol.1000885

Kinoshita, S., Wang, N., Inoue, H., Maeyama, K., Okamoto, K., Nagai, K., et al. (2011). Deep sequencing of ESTs from nacreous and prismatic layer producing tissues and a screen for novel shell formation-related genes in the pearl oyster. PLoS One 6:e21238. doi: 10.1371/journal.pone.0021238

Kishore, P., and Southgate, P. C. (2015). Haemocyte persistence after grafting for pearl production in Pinctada margaritifera (Linnaeus, 1758). Fish Shellfish Immunol. 42, 530-532. doi: 10.1016/j.fsi.2014.11.035

Kocot, K. M., Aguilera, F., Mcdougall, C., Jackson, D. J., and Degnan, B. M. (2016). Sea shell diversity and rapidly evolving secretomes: insights into the evolution of biomineralization. Front. Zool. 13:23. doi: 10.1186/s12983-016-0155-z

Kondrachuk, A. V., and Wiederhold, M. L. (2004). On generation of statoconia in gravireceptors of mollusks. Hear. Res. 197, 24-34. doi: 10.1016/j.heares.2004. 06.001

Kong, J., Liu, C., Yang, D., Yan, Y., Chen, Y., Huang, J., et al. (2018). Alv protein plays opposite roles in the transition of amorphous calcium carbonate to calcite and aragonite during shell formation. Cryst. Growth Des. 7, 3794-3804. doi: 10.1021/acs.cgd.8b00025 
Kong, W., Li, S., Xiang, L., Xie, L., and Zhang, R. (2015). Calcium carbonate mineralization mediated by in vitro cultured mantle cells from Pinctada fucata. Biochem. Biophys. Res. Commun. 7, 1053-1058. doi: 10.1016/j.bbrc.2015.06.057

Kong, Y., Jing, G., Yan, Z., Li, C., Gong, N., Zhu, F., et al. (2009). Cloning and characterization of Prisilkin-39, a novel matrix protein serving a dual role in the prismatic layer formation from the oyster Pinctada fucata. J. Biol. Chem. 284, 10841-10854. doi: 10.1074/jbc.M808357200

Kono, M., Hayashi, N., and Samata, T. (2000). Molecular mechanism of the nacreous layer formation in Pinctada maxima. Biochem. Biophys. Res. Commun. 269, 213-218. doi: 10.1006/bbrc.2000.2274

Kouchinsky, A. (2000). Shell microstructures in Early Cambrian molluscs. Acta Palaeontol. Pol. 45, 119-150.

Kylmaoja, E., Nakamura, M., and Tuukkanen, J. (2016). Osteoclasts and remodeling based bone formation. Curr. Stem Cell Res. Ther. 11, 626-633. doi: 10.2174/1574888X10666151019115724

Lee, S. W., Jang, Y. N., and Kim, J. C. (2011). Characteristics of the aragonitic layer in adult oyster shells, Crassostrea gigas: structural study of myostracum including the adductor muscle scar. Evid. Based Complement. Alternat. Med. 2011:742963. doi: 10.1155/2011/742963

Leggat, W., Dixon, R., Saleh, S., and Yellowlees, D. (2005). A novel carbonic anhydrase from the giant clam Tridacna gigas contains two carbonic anhydrase domains. FEBS J. 272, 3297-3305. doi: 10.1111/j.1742-4658.2005.04742.x

Li, S., Liu, Y., Liu, C., Huang, J., Zheng, G., Xie, L., et al. (2016). Hemocytes participate in calcium carbonate crystal formation, transportation and shell regeneration in the pearl oyster Pinctada fucata. Fish Shellfish Immunol. 51, 263-270. doi: 10.1016/j.fsi.2016.02.027

Liang, J., Xu, G., Xie, J., Lee, I., Liang, X., Wang, H., et al. (2015). Dual roles of the lysine-rich matrix protein (KRMP)-3 in shell formation of pearl oyster, Pinctada fucata. PLoS One 10:e0131868. doi: 10.1371/journal.pone.0131868

Liao, Z., Bao, L., Fan, M., Gao, P., Wang, X., Qin, C., et al. (2015). Indepth proteomic analysis of nacre, prism, and myostracum of Mytilus shell. J. Proteomics 122, 26-40. doi: 10.1016/j.jprot.2015.03.027

Liu, H., Liu, S., Ge, Y., Liu, J., Wang, X., Xie, L., et al. (2007). Identification and characterization of a biomineralization related gene PFMG1 highly expressed in the mantle of Pinctada fucata. Biochemistry 46, 844-851. doi: 10.1021/bi061881a

Lodi, M., and Koene, J. M. (2016). The love-darts of land snails: integrating physiology, morphology and behaviour. J. Molluscan Stud. 82:eyv046.

Lowenstam, H. A., and Weiner, S. (1989). On Biomineralization. New York, NY: Oxford University Press.

Ma, Z., Huang, J., Sun, J., Wang, G., Li, C., Xie, L., et al. (2007). A novel extrapallial fluid protein controls the morphology of nacre lamellae in the pearl oyster, Pinctada fucata. J. Biol. Chem. 282, 23253-23263. doi: 10.1074/jbc.M700001200

Mann, K., Siedler, F., Treccani, L., Heinemann, F., and Fritz, M. (2007). Perlinhibin, a cysteine-, histidine-, and arginine-rich miniprotein from abalone (Haliotis laevigata) nacre, inhibits in vitro calcium carbonate crystallization. Biophys. J. 93, 1246-1254. doi: 10.1529/biophysj.106.100636

Mann, K., Weiss, I. M., André, S., Gabius, H. J., and Fritz, M. (2000). The amino-acid sequence of the abalone (Haliotis laevigata) nacre protein perlucin. Detection of a functional C-type lectin domain with galactose/mannose specificity. Eur. J. Biochem. 267, 5257-5264. doi: 10.1046/j.1432-1327.2000. 01602.x

Mann, K., Edsinger-Gonzales, E., and Mann, M. (2012). In-depth proteomic analysis of a mollusc shell: acid-soluble and acid-insoluble matrix of the limpet Lottia gigantea. Proteome Sci. 10:28. doi: 10.1186/1477-5956-10-28

Marie, B., Arivalagan, J., Dubost, L., Berland, S., Marie, A., and Marin, F. D. R. (2015). Unveiling the evolution of bivalve nacre proteins by shell proteomics of unionoidae. Key Eng. Mater. 672, 158-167. doi: 10.4028/www.scientific.net/ KEM.672.158

Marie, B., Arivalagan, J., Mathéron, L., Bolbach, G., Berland, S., Marie, A., et al. (2017). Deep conservation of bivalve nacre proteins highlighted by shell matrix proteomics of the Unionoida Elliptio complanata and Villosa lienosa. J. R. Soc. Interface 14:20160846. doi: 10.1098/rsif.2016.0846

Marie, B., Jackson, D. J., Ramossilva, P., Zanellacléon, I., Guichard, N., and Marin, F. (2013). The shell-forming proteome of Lottia gigantea reveals both deep conservations and lineage-specific novelties. FEBS J. 280, 214-232. doi: 10.1111/febs. 12062

Marie, B., Joubert, C., Tayalé, A., Zanella-Cléon, I., Belliard, C., Piquemal, D., et al. (2012). Different secretory repertoires control the biomineralization processes of prism and nacre deposition of the pearl oyster shell. Proc. Natl. Acad. Sci. U.S.A. 109, 20986-20991. doi: 10.1073/pnas.1210552109

Marie, B., Marie, A., Jackson, D. J., Dubost, L., Degnan, B. M., Milet, C., et al. (2010). Proteomic analysis of the organic matrix of the abalone Haliotis asinina calcified shell. Proteome Sci. 8:54. doi: 10.1186/1477-5956-8-54

Marin, F., Corstjens, P., De Gaulejac, B., de Vrind-De Jong, E., and Westbroek, P. (2000). Mucins and molluscan calcification Molecular characterization of mucoperlin, a novel mucin-like protein from the nacreous shell layer of the fan mussel Pinna nobilis (Bivalvia, Pteriomorphia). J. Biol. Chem. 275, 2066720675. doi: 10.1074/jbc.M003006200

Marin, F., Le Roy, N., and Marie, B. (2012). The formation and mineralization of mollusk shell. Front. Biosci. 4, 1099-1125. doi: 10.2741/s321

Marin, F., Luquet, G., Marie, B., and Medakovic, D. (2008). Molluscan shell proteins: primary structure, origin, and evolution. Curr. Top. Dev. Biol. 80, 209-276. doi: 10.1016/S0070-2153(07)80006-8

Marin, F., Pokroy, B., Luquet, G., Layrolle, P., and Groot, K. D. (2007). Protein mapping of calcium carbonate biominerals by immunogold. Biomaterials 28 , 2368-2377. doi: 10.1016/j.biomaterials.2007.01.029

Marxen, J. C., Nimtz, M., Becker, W., and Mann, K. (2003). The major soluble 19.6 $\mathrm{kDa}$ protein of the organic shell matrix of the freshwater snail Biomphalaria glabrata is an N-glycosylated dermatopontin. Biochim. Biophys. Acta 1650, 92-98. doi: 10.1016/S1570-9639(03)00203-6

Masaoka, T., and Kobayashi, T. (2009). Analysis of nucleotide variation and inheritance of lysine-rich matrix protein (KRMP) genes participating in shell formation of pearl oyster. DNA Polymorphism 17, 126-135.

Mcdougall, C., Aguilera, F., and Degnan, B. M. (2013). Rapid evolution of pearl oyster shell matrix proteins with repetitive, low-complexity domains. J. R. Soc. Interface 10:20130041. doi: 10.1098/rsif.2013.0041

Michenfelder, M., Fu, G., Lawrence, C., Weaver, J. C., Wustman, B. A., Taranto, L., et al. (2003). Characterization of two molluscan crystal-modulating biomineralization proteins and identification of putative mineral binding domains. Biopolymers 70, 522-533. doi: 10.1002/bip.10536

Miyamoto, H., Endo, H., Hashimoto, N., Limura, K., Isowa, Y., Kinoshita, S., et al. (2013). The diversity of shell matrix proteins: genome-wide investigation of the pearl oyster, Pinctada fucata. Zoolog. Sci. 30, 801-816. doi: 10.2108/zsj.30.801

Miyamoto, H., Miyashita, T., Okushima, M., Nakano, S., Morita, T., and Matsushiro, A. (1996). A carbonic anhydrase from the nacreous layer in oyster pearls. Proc. Natl. Acad. Sci. U.S.A. 93, 9657-9660. doi: 10.1073/pnas.93.18.9657

Miyamoto, H., Miyoshi, F., and Kohno, J. (2005). The carbonic anhydrase domain protein nacrein is expressed in the epithelial cells of the mantle and acts as a negative regulator in calcification in the mollusc Pinctada fucata. Zoolog. Sci. 22, 311-315. doi: 10.2108/zsj.22.311

Miyamoto, H., Yano, M., and Miyashita, T. (2003). Similarities in the structure of nacrein, the shell-matrix protein, in a bivalve and a gastropod. J. Molluscan Stud. 69, 87-89. doi: 10.1093/mollus/69.1.87

Miyashita, T., Takagi, R., Miyamoto, H., and Matsushiro, A. (2002). Identical carbonic anhydrase contributes to nacreous or prismatic layer formation in Pinctada fucata (Mollusca: Bivalvia). Veliger 45, 250-255.

Miyashita, T., Takagi, R., Okushima, M., Nakano, S., Miyamoto, H., Nishikawa, E., et al. (2000). Complementary DNA cloning and characterization of pearlin, a new class of matrix protein in the nacreous layer of oyster pearls. Mar. Biotechnol. 2, 409-418.

Miyashita, T., Takami, A., and Takagi, R. (2012). Molecular cloning and characterization of the $5^{\prime}$-flanking regulatory region of the carbonic anhydrase nacrein gene of the pearl oyster Pinctada fucata and its expression. Biochem. Genet. 50, 673-683. doi: 10.1007/s10528-012-9510-8

Miyazaki, Y., Nishida, T., Aoki, H., and Samata, T. (2010). Expression of genes responsible for biomineralization of Pinctada fucata during development. Comp. Biochem. Physiol. B Biochem. Mol. Biol. 155, 241-248. doi: 10.1016/j. cbpb.2009.11.009

Morse, J. W., Arvidson, R. S., and Lüttge, A. (2007). Calcium carbonate formation and dissolution. Chem. Rev. 107, 342-381. doi: 10.1021/cr050358j

Mount, A., and Pickering, C. M. (2009). Testing the capacity of clothing to act as a vector for non-native seed in protected areas. J. Environ. Manage. 91, 168-179. doi: 10.1016/j.jenvman.2009.08.002

Mount, A. S., Wheeler, A., Paradkar, R. P., and Snider, D. (2004). Hemocytemediated shell mineralization in the eastern oyster. Science 304, 297-300. doi: 10.1126/science. 1090506 
Nam, B. H., Kwak, W., Kim, Y. O., Kim, D. G., Kong, H. J., Kim, W. J., et al. (2017). Genome sequence of pacific abalone (Haliotis discus hannai): the first draft genome in family Haliotidae. Gigascience 6, 1-8. doi: 10.1093/gigascience/ gix014

Norizuki, M., and Samata, T. (2008). Distribution and function of the nacreinrelated proteins inferred from structural analysis. Mar. Biotechnol. 10, 234-241. doi: 10.1007/s10126-007-9061-x

Nudelman, F., Gotliv, B. A., Addadi, L., and Weiner, S. (2006). Mollusk shell formation: mapping the distribution of organic matrix components underlying a single aragonitic tablet in nacre. J. Struct. Biol. 153, 176-187. doi: 10.1016/j. jsb.2005.09.009

Pan, C., Fang, D., Xu, G., Liang, J., Zhang, G., Wang, H., et al. (2014). A novel acidic matrix protein, PfN44, stabilizes magnesium calcite to inhibit the crystallization of aragonite. J. Biol. Chem. 289, 2776-2787. doi: 10.1074/jbc.M113.504027

Politi, Y., Mahamid, J., Goldberg, H., Weiner, S., and Addadi, L. (2007). Asprich mollusk shell protein: in vitro experiments aimed at elucidating function in CaCO3 crystallization. Crystengcomm 9, 1171-1177. doi: 10.1039/b709749b

Rahman, M. A., and Shinjo, R. (2012). "Control of CaCO3 crystal growth by the acidic proteinaceous fraction of calcifying marine organisms: an in vitro study of biomineralization," in Advanced Topics in Biomineralization, ed. J. Seto (London: InTech).

Saadi, I., Das, P., Zhao, M., Raj, L., Ruspita, I., Xia, Y., et al. (2013). Msx1 and Tbx2 antagonistically regulate Bmp4 expression during the bud-to-cap stage transition in tooth development. Development 140, 2697-2702. doi: 10.1242/ dev.088393

Saha, A., Jana, T., and Choudhury, A. (1988). The extrapallial fluid of Macoma birmanica: an environment for calcium carbonate deposition. Philipp. J. Crop Sci. 117, 395-399.

Samata, T., Hayashi, N., Kono, M., Hasegawa, K., Horita, C., and Akera, S. (1999). A new matrix protein family related to the nacreous layer formation of Pinctada fucata. FEBS Lett. 462, 225-229. doi: 10.1016/S0014-5793(99)01387-3

Sarashina, I., and Endo, K. (1998). Primary structure of a soluble matrix protein of scallop shell: implications for calcium carbonate biomineralization. Am. Mineral. 83, 1510-1515. doi: 10.2138/am-1998-11-1239

Saruwatari, K., Matsui, T., Mukai, H., Nagasawa, H., and Kogure, T. (2009). Nucleation and growth of aragonite crystals at the growth front of nacres in pearl oyster, Pinctada fucata. Biomaterials 30, 3028-3034. doi: 10.1016/j. biomaterials.2009.03.011

Shen, X., Belcher, A. M., Hansma, P. K., Stucky, G. D., and Morse, D. E. (1997). Molecular cloning and characterization of lustrin A, a matrix protein from shell and pearl nacre of Haliotis rufescens. J. Biol. Chem. 272, 32472-32481. doi: 10.1074/jbc.272.51.32472

Shi, M., Lin, Y., Xu, G., Xie, L., Hu, X., Bao, Z., et al. (2013). Characterization of the zhikong scallop (Chlamys farreri) mantle transcriptome and identification of biomineralization-related genes. Mar. Biotechnol. 15, 706-715. doi: 10.1007/ s10126-013-9517-0

Shitalbahen, V. P. (2004). A Novel Function of Invertebrate Collagen in the Biomineralization Process During the Shell Repair of Eastern Oyster, Crassostrea virginica. Clemson, SC: Clemson University.

Sikes, C. S., Wheeler, A. P., Wierzbicki, A., Mount, A. S., and Dillaman, R. M. (2000). Nucleation and growth of calcite on native versus pyrolyzed oyster shell folia. Biol. Bull. 198, 50-66. doi: 10.2307/1542803

Simkiss, K., and Wilbur, K. M. (1989). Biomineralization: Cell Biology and Mineral Deposition. San Diego, CA: Academic Press.

Sleight, V. A., Thorne, M. A., Peck, L. S., and Clark, M. S. (2015). Transcriptomic response to shell damage in the Antarctic clam, Laternula elliptica: time scales and spatial localisation. Mar. Genomics 20, 45-55. doi: 10.1016/j.margen.2015. 01.009

Smith-Keune, C., and Jerry, D. R. (2009). High levels of intra-specific variation in the NG repeat region of the Pinctada maxima N66 organic matrix protein. Aquac. Res. 40, 1054-1063. doi: 10.1111/j.1365-2109.2009.02199.x

Song, X., Wang, X., Li, L., and Zhang, G. (2014). Identification two novel nacreinlike proteins involved in the shell formation of the Pacific oyster Crassostrea gigas. Mol. Biol. Rep. 41, 4273-4278. doi: 10.1007/s11033-014-3298-z

Song, X., Wang, X., Li, L., and Zhang, G. (2015). Molecular cloning and characterization of nacrein gene in Pacific oyster (Crassostrea gigas). Mar. Sci. 39:9.
Stenzel, H. (1963). Aragonite and calcite as constituents of adult oyster shells. Science 142, 232-233. doi: 10.1126/science.142.3589.232

Su, J., Liang, X., Zhou, Q., Zhang, G., Wang, H., Xie, L., et al. (2013). Structural characterization of amorphous calcium carbonate-binding protein: an insight into the mechanism of amorphous calcium carbonate formation. Biochem. J. 453, 179-186. doi: 10.1042/BJ20130285

Sudo, S., Fujikawa, T., Nagakura, T., Ohkubo, T., Sakaguchi, K., Tanaka, M., et al. (1997). Structures of mollusc shell framework proteins. Nature 387, 563-564. doi: 10.1038/42391

Sun, J., Xu, G., Wang, Z., Li, Q., Cui, Y., Xie, L., et al. (2015). The effect of NF-kappaB signalling pathway on expression and regulation of nacrein in pearl oyster, Pinctada fucata. PLoS One 10:e0131711. doi: 10.1371/journal.pone. 0131711

Suzuki, M., Iwashima, A., Kimura, M., Kogure, T., and Nagasawa, H. (2013). The molecular evolution of the Pif family proteins in various species of mollusks. Mar. Biotechnol. 15, 145-158. doi: 10.1007/s10126-012-9471-2

Suzuki, M., Iwashima, A., Tsutsui, N., Ohira, T., Kogure, T., and Nagasawa, H. (2011). Identification and characterisation of a calcium carbonate-binding protein, blue mussel shell protein (BMSP), from the nacreous layer. Chembiochem 12, 2478-2487. doi: 10.1002/cbic.201100317

Suzuki, M., Murayama, E., Inoue, H., Ozaki, N., Tohse, H., Kogure, T., et al. (2004). Characterization of Prismalin-14, a novel matrix protein from the prismatic layer of the Japanese pearl oyster (Pinctada fucata). Biochem. J. 382(Pt 1), 205-213. doi: 10.1042/BJ20040319

Suzuki, M., and Nagasawa, H. (2007). The structure-function relationship analysis of Prismalin-14 from the prismatic layer of the Japanese pearl oyster, Pinctada fucata. FEBS J. 274, 5158-5166. doi: 10.1111/j.1742-4658.2007.06036.x

Suzuki, M., Saruwatari, K., Kogure, T., Yamamoto, Y., Nishimura, T., Kato, T., et al. (2009). An acidic matrix protein, Pif, is a key macromolecule for nacre formation. Science 325, 1388-1390. doi: 10.1126/science.1173793

Takeuchi, T., Koyanagi, R., Gyoja, F., Kanda, M., Hisata, K., Fujie, M., et al. (2016). Bivalve-specific gene expansion in the pearl oyster genome: implications of adaptation to a sessile lifestyle. Zoological Lett. 2:3. doi: 10.1186/s40851-0160039-2

Takeuchi, T., Sarashina, I., Iijima, M., and Endo, K. (2008). In vitro regulation of $\mathrm{CaCO} 3$ crystal polymorphism by the highly acidic molluscan shell protein Aspein. FEBS Lett. 582, 591-596. doi: 10.1016/j.febslet.2008.01.026

Tang, R., Wang, X., Liu, X., Xiao, Y., Hao, H., and Zhang, Y. (2018). Biomineralization state of viruses and their biological potentials. Chemistry 24, 11518-11529. doi: 10.1002/chem.201705936

Todt, C., and Wanninger, A. (2010). Of tests, trochs, shells, and spicules: development of the basal mollusk Wirenia argentea (Solenogastres) and its bearing on the evolution of trochozoan larval key features. Front. Zool. 7:6. doi: 10.1186/1742-9994-7-6

Tokuyama, A. (1969). Effects of organic matter on solubilities and crystal form of carbonates. Am. Zool. 9, 681-688. doi: 10.1093/icb/9.3.681

Treccani, L., Mann, K., Heinemann, F., and Fritz, M. (2006). Perlwapin, an abalone nacre protein with three four-disulfide core (Whey Acidic Protein) domains, inhibits the growth of calcium carbonate crystals. Biophys. J. 91, 2601-2608. doi: 10.1529/biophysj.106.086108

Trinkler, N., Bardeau, J. F., Marin, F., Labonne, M., Jolivet, A., Crassous, P., et al. (2011). Mineral phase in shell repair of Manila clam Venerupis philippinarum affected by brown ring disease. Dis. Aquat. Organ. 93, 149-162. doi: 10.3354/ dao02288

Tsukamoto, D., Sarashina, I., and Endo, K. (2004). Structure and expression of an unusually acidic matrix protein of pearl oyster shells. Biochem. Biophys. Res. Commun. 320, 1175-1180. doi: 10.1016/j.bbrc.2004.06.072

Wang, S., Zhang, J., Jiao, W., Li, J., Xun, X., Sun, Y., et al. (2017). Scallop genome provides insights into evolution of bilaterian karyotype and development. Nat. Ecol. Evol. 1:0120.

Wang, X., Li, L., Zhu, Y., Du, Y., Song, X., Chen, Y., et al. (2013a). Oyster shell proteins originate from multiple organs and their probable transport pathway to the shell formation front. PLoS One 8:e66522. doi: 10.1371/journal.pone. 0066522

Wang, X., Song, X., Wang, T., Zhu, Q., Miao, G., Chen, Y., et al. (2013b). Evolution and functional analysis of the Pif97 gene of the Pacific oyster Crassostrea gigas. Curr. Zool. 59, 109-115. doi: 10.1093/czoolo/59.1.109 
Wang, Y., Xia, J., Tang, R., et al. (2011). Cloning and characterization of nacrerelated genes in silver-lip pearl oyster Pinctada maxima. J. Shanghai Ocean Univ. 1:003.

Watabe, N. (1965). Studies on shell formation. XI. Crystal-matrix relationships in the mollusk shells. J. Ultrastruct. Res. 12, 351-370. doi: 10.1016/S0022-5320(65) 80104-6

Weiner, S., and Addadi, L. (2011). Crystallization pathways in biomineralization. Cells Tissues Organs 41, 21-40.

Weiss, I. M., Göhring, W., Fritz, M., and Mann, K. (2001). Perlustrin, a Haliotis laevigata (Abalone) nacre protein, is homologous to the insulin-like growth factor binding protein N-terminal module of vertebrates. Biochem. Biophys. Res. Commun. 285, 244-249. doi: 10.1006/bbrc.2001.5170

Weiss, I. M., Kaufmann, S., Mann, K., and Fritz, M. (2000). Purification and characterization of perlucin and perlustrin, two new proteins from the shell of the mollusc Haliotis laevigata. Biochem. Biophys. Res. Commun. 267, 17-21. doi: 10.1006/bbrc.1999.1907

Werner, G. D., Gemmell, P., Grosser, S., Hamer, R., and Shimeld, S. M. (2013). Analysis of a deep transcriptome from the mantle tissue of Patella vulgata Linnaeus (Mollusca: Gastropoda: Patellidae) reveals candidate biomineralising genes. Mar. Biotechnol. 15, 230-243. doi: 10.1007/s10126-012-9481-0

Wilbur, K., and Saleuddin, A. (1983). Shell formation. Mollusca 4, 235-287. doi: 10.1016/B978-0-12-751404-8.50014- 1

Wilbur, K. M., and Bernhardt, A. M. (1984). Effects of amino acids, magnesium, and molluscan extrapallial fluid on crystallization of calcium carbonate: in vitro experiments. Biol. Bull. 166, 251-259. doi: 10.2307/1541446

Wilt, F. H. (2002). Biomineralization of the spicules of sea urchin embryos. Zoolog. Sci. 19, 253-261. doi: 10.2108/zsj.19.253

Xiang, L., Kong, W., Su, J. T., Liang, J., Zhang, G. Y., Xie, L. P., et al. (2014). Amorphous calcium carbonate precipitation by cellular biomineralization in mantle cell cultures of Pinctada fucata. PLoS One 9:e113150. doi: 10.1371/ journal.pone.0113150

Xie, J. (2016). The Mechanism Study of Extrapallial Fluid Protein in the Shell Formation of Pinctada fucata. Beijing Shi: Tsinghua University.

Xie, J., Liang, J., Sun, J., Gao, J., Zhang, S., Liu, Y., et al. (2016). Influence of the extrapallial fluid of Pinctada fucata on the crystallization of calcium carbonate and shell biomineralization. Cryst. Growth Des. 16, 672-680. doi: 10.1021/acs. cgd.5b01203

Yan, Z., Jing, G., Gong, N., Li, C., Zhou, Y., Xie, L., et al. (2007). N40, a novel nonacidic matrix protein from pearl oyster nacre, facilitates nucleation of aragonite in vitro. Biomacromolecules 8, 3597-3601. doi: 10.1021/bm07 01494

Yano, M., Nagai, K., Morimoto, K., and Miyamoto, H. (2006). Shematrin: a family of glycine-rich structural proteins in the shell of the pearl oyster Pinctada fucata. Comp. Biochem. Physiol. B Biochem. Mol. Biol. 144, 254-262. doi: 10.1016/j. cbpb.2006.03.004

Yano, M., Nagai, K., Morimoto, K., and Miyamoto, H. (2007). A novel nacre protein N19 in the pearl oyster Pinctada fucata. Biochem. Biophys. Res. Commun. 362, 158-163. doi: 10.1016/j.bbrc.2007.07.172
Yi, Y., Dong, Y., Xue, Y., Liu, C., Xie, J., Zheng, G., et al. (2017). A novel matrix protein, PfY2, functions as a crucial macromolecule during shell formation. Sci. Rep. 7:6021. doi: 10.1038/s41598-017-06375-w

Yin, H., Ji, B., Dobson, P. S., Mosbahi, K., Glidle, A., Gadegaard, N., et al. (2009). Screening of biomineralization using microfluidics. Anal. Chem. 81, 473-478. doi: 10.1021/ac801980b

Yin, Y., Huang, J., Paine, M. L., Reinhold, V. N., and Chasteen, N. D. (2005). Structural characterization of the major extrapallial fluid protein of the mollusc Mytilus edulis: implications for function. Biochemistry 44, 10720-10731. doi: 10.1021/bi0505565

Yu, Z., Xie, L., Lee, S., and Zhang, R. (2006). A novel carbonic anhydrase from the mantle of the pearl oyster (Pinctada fucata). Comp. Biochem. Physiol. B Biochem. Mol. Biol. 143, 190-194. doi: 10.1016/j.cbpb.2005.11.006

Zhang, C., Li, S., Ma, Z., Xie, L., and Zhang, R. (2006a). A novel matrix protein p10 from the nacre of pearl oyster (Pinctada fucata) and its effects on both $\mathrm{CaCO} 3$ crystal formation and mineralogenic cells. Mar. Biotechnol. 8, 624-633. doi: 10.1007/s10126-006-6037-1

Zhang, C., Xie, L., Huang, J., Liu, X., and Zhang, R. (2006b). A novel matrix protein family participating in the prismatic layer framework formation of pearl oyster, Pinctada fucata. Biochem. Biophys. Res. Commun. 344, 735-740. doi: 10.1016/j.bbrc.2006.03.179

Zhang, C., and Zhang, R. (2006). Matrix proteins in the outer shells of molluscs. Mar. Biotechnol. 8, 572-586. doi: 10.1007/s10126-005-6029-6

Zhang, G., Fang, X., Guo, X., Li, L., Luo, R., Xu, F., et al. (2012). The oyster genome reveals stress adaptation and complexity of shell formation. Nature 490, 49-54. doi: 10.1038/nature11413

Zhang, Y., Xie, L., Meng, Q., Jiang, T., Pu, R., Chen, L., et al. (2003). A novel matrix protein participating in the nacre framework formation of pearl oyster, Pinctada fucata. Comp. Biochem. Physiol. B Biochem. Mol. Biol. 135, 565-573. doi: 10.1016/S1096-4959(03)00138-6

Zhao, M., He, M., Huang, X., and Wang, Q. (2014). A homeodomain transcription factor gene, PfMSX, activates expression of Pif gene in the pearl oyster Pinctada fucata. PLoS One 9:e103830. doi: 10.1371/journal.pone.0103830

Zheng, X., Cheng, M., Xiang, L., Liang, J., Xie, L., and Zhang, R. (2015). The AP-1 transcription factor homolog Pf-AP-1 activates transcription of multiple biomineral proteins and potentially participates in Pinctada fucata biomineralization. Sci. Rep. 5:14408. doi: 10.1038/srep14408

Conflict of Interest Statement: The authors declare that the research was conducted in the absence of any commercial or financial relationships that could be construed as a potential conflict of interest.

Copyright (c) 2019 Song, Liu, Wang and Song. This is an open-access article distributed under the terms of the Creative Commons Attribution License (CC BY). The use, distribution or reproduction in other forums is permitted, provided the original author(s) and the copyright owner(s) are credited and that the original publication in this journal is cited, in accordance with accepted academic practice. No use, distribution or reproduction is permitted which does not comply with these terms. 